\title{
Interannual climate variation, land type and village livelihood effects on fires in Kalimantan, Indonesia
}

\section{Authors}

Truly Santika ${ }^{1,2,3, *}$, Sugeng Budiharta ${ }^{2,4}$, Elizabeth A. Law ${ }^{2,5,6}$, Rona A. Dennis ${ }^{3}$, Alue Dohong ${ }^{7,8,9}$, Matthew J. Struebig ${ }^{10}$, Medrilzam ${ }^{9,11}$, Haris Gunawan ${ }^{7}$, Erik Meijaard ${ }^{2,3,10}$ \& Kerrie A. Wilson ${ }^{2,12}$

\section{Author affiliations}

1 Natural Resources Institute (NRI), University of Greenwich, Chatham Maritime, ME4 4TB, UK

2 ARC Centre of Excellence for Environmental Decisions, The University of Queensland, Brisbane, Australia

3 Borneo Futures, Brunei Darussalam

4 Purwodadi Botanic Garden - Indonesian Institute of Sciences (LIPI), Pasuruan, Jawa Timur, Indonesia

5 Humboldt-Universität zu Berlin, Geography Department, 10099 Berlin, Germany

$6 \quad$ Norwegian Institute for Nature Research (NINA), Trondheim, Norway

7 Peatland Restoration Agency (BRG) Indonesia, Jakarta, Indonesia

8 University of Palangka Raya (UPR), Palangka Raya, Kalimantan Tengah, Indonesia

9 The University of Queensland (UQ), School of Earth and Environmental Sciences, Brisbane, Australia

10 Durrell Institute of Conservation and Ecology (DICE), School of Anthropology and Conservation, University of Kent, Canterbury, CT2 7NR, UK

11 Ministry of National Development Planning Indonesia (BAPPENAS), Jakarta 10310, Indonesia

12 Institute for Future Environments (IFE), Queensland University of Technology (QUT), Brisbane, Australia

* Corresponding author

Truly Santika <T.Santika@greenwich.ac.uk>

\section{Acknowledgements}

This study was supported by the Australian Research Council Centre of Excellence for Environmental Decisions, Future Fellowship and Discovery program, and the Arcus Foundation. 


\section{Interannual climate variation, land type and village livelihood effects on fires in Kalimantan, Indonesia}

\section{Abstract}

The increasing extent and frequency of fires globally requires nuanced understanding of the drivers of largescale events for improved prevention and mitigation. Yet, the drivers of fires are often poorly understood by various stakeholders in spatially expansive and temporally dynamic landscapes. Further, perceptions about the main cause of fires vary amongst stakeholders, which amplify ongoing challenges from policies being implemented inconsistently across different governance levels. Here, we develop a spatially and temporallyexplicit typology of fire prevalence across Kalimantan, Indonesia, a region with significant contribution to global greenhouse gas emissions. Based on livelihood information and data on climate, soil type and forest degradation status, we find that in intact forest the density of fires in villages that largely coincide with oil palm concessions was twice as high as in villages outside the concessions across all years. Fires occurring in degraded land on mineral soil across all years were also most prevalent in villages with industrial plantations (oil palm or timber). On the other hand, in degraded peatland, where fires are most intense during dry years induced by the El Niño episodes, occurrence rates were high regardless of village primary livelihoods. Based on these findings we recommend two key priorities for fire mitigation going forward for policy across different governance levels in Kalimantan: degraded peatland as the priority area and industrial plantations as the priority sector. Our study suggests a fire prevention and mitigation approach, which accounts for climate, land type and village livelihood, has the potential to deliver more effective means of management.

Key-words: fire typology; industrial plantations; peatland; policy discourse; spatio-temporal analysis; subsistence livelihoods; zero burning 


\section{Introduction}

Devastating fires have become more frequent in Indonesia over the past three decades (Field et al. 2016). Globally, the severity of these fires places Indonesia as the largest contributor to global greenhouse gas emissions from deforestation and land use change (Van der Werf 2015). Furthermore, fires pose a significant threat to national and regional health, biodiversity and ecosystem service provision, and economic growth (Marlier et al. 2013; Meijaard 2018). Fires are particularly severe and exacerbated during drought years induced by El Niño events (Parker et al. 2016; Taufik et al. 2017). For example, during the strong El Niño of 2015, the resulting daily carbon dioxide emissions from Indonesian fires exceeded the average daily emissions from the entire USA (Huijnen et al. 2016).

Although fire has long been used by farmers across Southeast Asia to clear land, large-scale clearance by various actors has amplified the consequences of this practice (Murdiyarso \& Lebel 2007; Gaveau et al. 2017). Mismanagement of peatland, which was previously marginal to production, through drainage and conversion of peat forest to agricultural land has further exacerbated the problem by substantially increasing fuel loads and associated fire risk (Wijedasa et al. 2017). The Indonesian islands of Sumatra and Kalimantan (Indonesian Borneo) are the largest contributors to carbon emissions and toxic smoke haze (Huijnen et al. 2016), mainly due to the large extent of degraded peatland. Here, fires are predominantly of anthropogenic origin, and typically increase dramatically during the driest season between August and October (Permadi \& Oanh 2013) (Fig. 1a), as fire is a widely deployed tool for preparing land for planting of crops, both subsistence food and commercial (Harrison et al. 2009).

The attribution for uncontrolled vegetation fires in Indonesia is highly contested. Some studies indicate that fire has mostly occurred inside oil palm and timber plantation concessions, but other studies reveal ignition events to be associated with small-scale farmers and local communities, either intentionally or accidentally (Marlier et al. 2015; Cattau et al. 2016; Gaveau et al. 2017). Perceptions vary between stakeholders regarding the most suitable type of fire prevention and mitigation measures (Harwell 2000; Forsyth 2014). A study by Carmenta et al. (2017) shows there were significant differences in the type of fire management prioritized by different stakeholders and governance levels. Local regency and village leaders tend to share the perceptions of smallholders on the benefit and burden of fire and they opt for imposing context-based fire management policy and strengthening fire fighting rather than a total ban on burning. In contrast, the agro-industrial concessionaires shared the perceptions held by higher-level policymakers (provincial, national and international) who favour a fire ban (Carmenta et al. 2017). These polarized views suggest that fire management policies created at provincial and national levels are likely to face critical challenges for implementation on the ground by local government and communities, which hampers the overall effectiveness of fire prevention and mitigation in efforts to mitigate climate change. 
In the wake of the 2015 fire crisis, the Indonesian government implemented tougher fire prevention measures across Kalimantan and Sumatra (as legislated in the Presidential Instruction No. 11/2015). In 2016 and 2017, the number of fire hotspots was markedly reduced, although during these two years precipitation during the driest season was much higher than the preceding years (Fig. 1b and Fig. S1 in the Supplementary Material). Given that Indonesia is expected to experience more frequent and severe drought in the future (Cai et al. 2014), and demand for oil palm - a key driver of land conversion - it is critical to rigorously assess the drivers of fire to enhance fire management policy going forward. In addition, Indonesia's new one-size-fits-all policy, i.e. fire policy implemented uniformly across different geographies and stakeholder groups, has been criticized by local leaders, indigenous movements and media outlets for disadvantaging local communities who typically rely on controlled burning for subsistence agriculture on mineral soils (Rohadi 2017; Thung 2018).

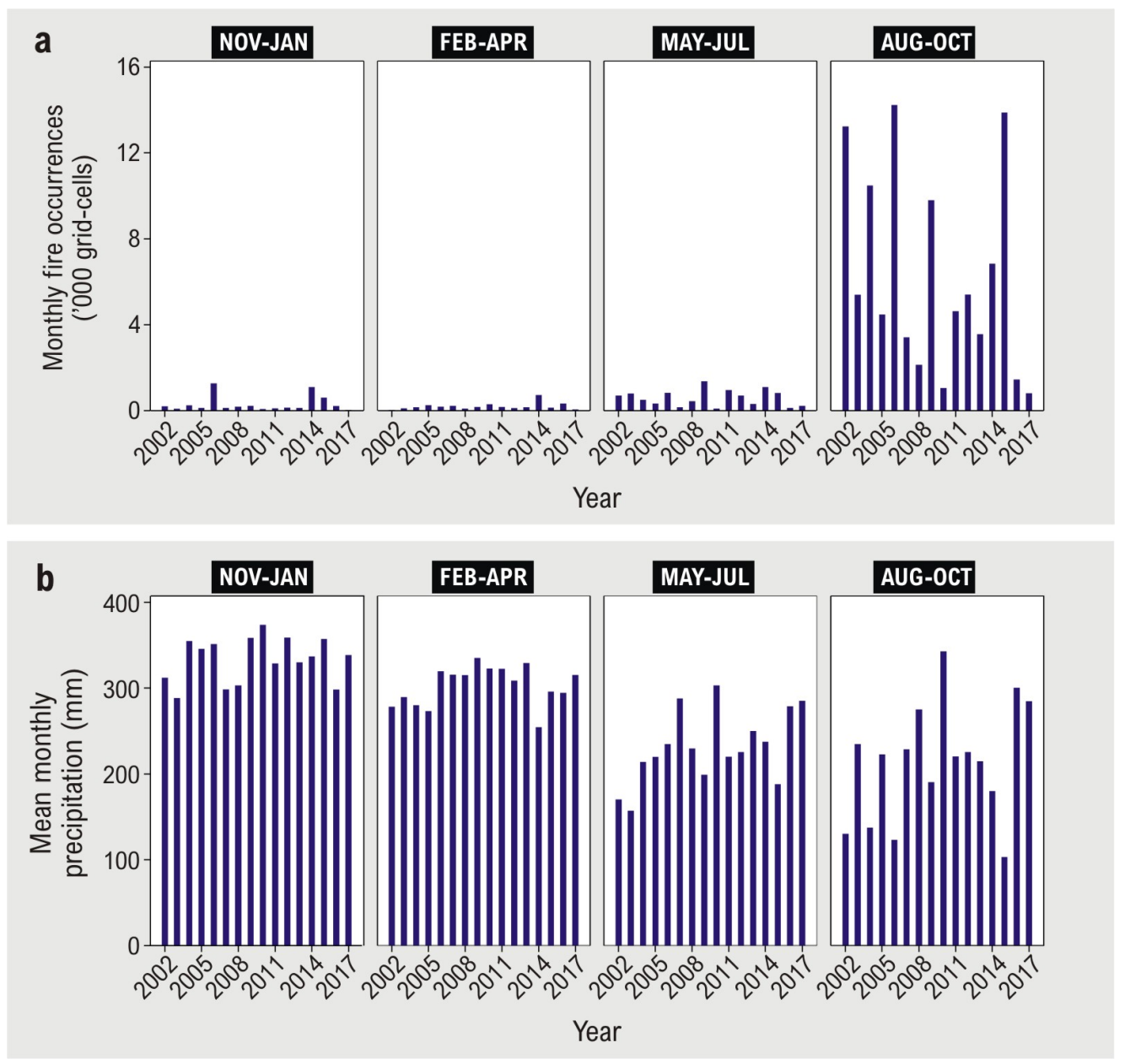

Fig. 1. Interannual variability in fire and precipitation in Kalimantan. Annual variability in (a) mean monthly fire occurrences ( $1 \times 1 \mathrm{~km}^{2}$ grid-cells) detected by the Moderate Resolution Imaging Spectroradiometer (MODIS) MCD14ML data, and (b) mean monthly precipitation, in November-January, February-April, May-July, and AugustOctober, between 2002 and 2017 across Kalimantan based on the Climate Hazards Group InfraRed Precipitation with Station (CHIRPS) data. 
Landscape studies on the drivers of fire in Indonesia typically fall into two broad themes: (1) broadscale analysis (either national, island, or regional-wide studies) of the impact of El Niño events and land type (soil and land cover), and (2) local-scale analysis of the impact of land type (soil and land cover) and community characteristics (livelihoods, land tenure, stakeholders, political economy) (Table S1). While the former mainly focused on the broad biophysical processes (climate and hydrology) driving fire occurrences, the latter tended to focus on detailed social (socioeconomic and socio-political) aspects. Assessment of the drivers of fire occurrence across broad spatiotemporal scales that accounts for both biophysical and social processes (i.e. annual climate variability, land types, and village livelihood characteristics) has not previously been undertaken, hampered mainly by the lack of spatiotemporal data of social measures over broad areas. Yet, such a classification is imperative to provide a comprehensive understanding of fire occurrence patterns. Further, recognizing the complexity of fire occurrence allows for a better appreciation of how divergent views on fire have arisen across stakeholder groups in the context of dynamic landscapes. Moreover, such scrutiny should help identify appropriate mitigation measures with clear lines of responsibility to inform constructive multi-level government discussions that could enhance the success of fire policy objectives in the long term (Dennis et al. 2005; Thung 2018).

Here we developed a spatially and temporally-explicit typology of fire occurrences in Kalimantan (531,000 km²), Indonesia, between 2002 and 2017. We aimed to address two research questions. First, how does the occurrence of fire (both intentionally ignited and escaped fire) vary across climate, land type, and village livelihoods? Second, what are the priority areas and the priority sectors for fire mitigation measures going forward for policy across different governance levels? Numerous studies have shown that climate variability, especially droughts during the El Niño episodes, have profound impacts on fire (Fanin \& Van der Werf 2017; Pan et al. 2018). Peatlands that have been deforested and degraded are particularly vulnerable to recurring fire and the associated emissions, compared to lands on mineral soil (Page \& Hooijer 2016; Taufik et al. 2017). Studies have also shown that fires tend to be more prevalent inside or nearby to industrial-scale plantation concessions (Cattau et al. 2016; Sloan et al. 2017), and these fires can arise from various motives (e.g. land clearing or tenure conflicts) involving various actors (i.e. plantation companies, small farmers, and local communities) (Gaveau et al. 2017; Purnomo et al. 2017; Sze \& Lee 2019). Further, traditional subsistence (swidden) communities have often been accused of being one of the contributors to catastrophic fires in Indonesia (Cramb et al. 2009; Fox et al. 2014). Thus, there is ample evidence showing that climate (i.e. interannual rainfall variability), land type (i.e. soil and forest degradation status), and village livelihoods (i.e. the livelihood in which most people derive their income and the presence of agro-industrial and forest concessions) are important drivers of fires in Indonesia. However, how these variables concurrently affect patterns of fire occurrence is yet to be assessed more thoroughly. Our approach for assessing fire typology over broad area taking into accounts both biophysical and social drivers is novel and has never been conducted for Indonesia. 


\section{Material and methods}

\subsection{Data}

\subsubsection{Fire occurrence}

Daily fire detections at $1 \mathrm{~km}$ pixel resolution across Kalimantan from 2002 to 2017 were obtained from the Moderate Resolution Imaging Spectroradiometer (MODIS) fire detection data MCD14ML product Collection 6 (Giglio 2015). These data include fires detected by either the Terra or Aqua MODIS sensor. The data contain information about location of the centre of the $1 \mathrm{~km}$ pixel in which fire was detected, the date and time of detection, the Fire Radiative Power (FRP) as a measure of fire or heat intensity, and the detection confidence. Low FRP value can either represent a relatively small or confined hot fire, or cooler or smouldering fire (Riley et al. 2016). FRP has often been used to estimate fire emission rates (Ichoku \& Ellison 2014; Mota \& Wooster 2018). To avoid potential false detection resulting from non-fire heat signatures, we included only fire detections with confidence level higher than 30\% (As-syakur et al. 2013).

To validate the results of fire analyses derived from the MODIS data, we used the daily fire detection obtained from the Visible Infrared Imaging Radiometer Suite (VIIRS) VNP14_IMG product at 375 m pixel resolution across the island (Schroeder et al. 2014). The data also contain information about location of the centre of the $375 \mathrm{~m}$ pixel in which fire was detected, the date and time of detection, the FRP, and the detection confidence, but only available from 2012 to 2017. To avoid potential false detection, we excluded fire with low confidence level, i.e. flagged with "l".

\subsubsection{Interannual climate variability}

Monthly precipitation estimates at $5 \mathrm{~km}$ resolution across the island from 2000 to 2017 were obtained from the recently developed Climate Hazards Group InfraRed Precipitation with Station (CHIRPS) dataset (Funk et al. 2015). The data were derived by combining three main data sources: the Climate Hazards group Precipitation climatology (CHPclim) (i.e. a global precipitation climatology at $0.05^{\circ}$ resolution estimated for each month based on station data, averaged satellite observations, elevation, latitude and longitude), satellite precipitation estimates from TMPA (Tropical Rainfall Measuring Mission (TRMM) Multisatellite Precipitation Analysis), and rain gauge measurements (Funk et al. 2015). We used the CHIRPS dataset due to its high spatial resolution in comparison to satellite-based-only rainfall data, such as the TMPA 3B43 data (Huffman et al. 2007) which has a spatial resolution of $25 \mathrm{~km}$.

Due to its recent development, CHIRPS datasets have been validated only in few areas in Indonesia outside the island of Kalimantan (e.g. Setiawan et al. 2017; Sugiarto et al. 2018), but are superior in predicting rainfall gauge observations across China (Bai et al. 2018), Nepal (Shrestha et al. 2017), Brazil (Paredes-Trejo et 
al. 2017), and countries in Eastern Africa (Dinku et al. 2018). On the other hand, the TMPA datasets have been evaluated more thoroughly due to the earlier development of the TRMM precipitation detection program, and the TMPA data accurately predicts rainfall observation from rain gauge observations across Indonesia (Vernimmen et al. 2012; As-syakur et al. 2013) and in other countries (Franchito et al. 2009; Prakash \& Gairola 2014). To evaluate the reliability of the CHIRPS dataset for Kalimantan, we applied two approaches. First, we compared the dataset with the TMPA data every month between 2000 and 2017. Second, we validated the dataset against the monthly rain gauge observations obtained from 20 major meteorological stations across Kalimantan over the same period (Fig. S2a), obtained from the Meteorology, Climatology, and Geophysical Agency Indonesia (BMKG 2019).

We obtained a good agreement between the CHIRPS and the TMPA datasets (average Pearson correlation of 0.74 across different seasons and climate regimes; Fig. S2c). We also obtained a good agreement between the CHIRPS dataset and the in situ rain gauge observations (average Pearson correlation of 0.72; Fig. S2b). This suggests that CHIRPS data provide a good estimation of spatiotemporal changes of rainfall across Kalimantan.

\subsubsection{Land types}

Land type was defined based on the type of soil (i.e. peat or mineral soil) and forest degradation status (i.e. degraded or intact forest). Peat soil is accumulation of partially decayed vegetation or organic matter, whereas mineral soil is derived from minerals or rocks and containing little organic matter. The peatland ecosystem is a vital carbon sink, as the associated vegetation captures carbon-dioxide naturally released from the peat to maintain equilibrium. Data on soil type were obtained from the Peatland Hydrological Unit map provided by the Indonesian Ministry of Environment and Forestry (MEF 2017), with a resolution of $125 \mathrm{~m}$. Forest degradation status each year between 2001 and 2017 was estimated by overlaying the extent of natural forest across Indonesia in 2000 provided by Margono et al. (2014) and the annual forest loss derived from the Global Forest Change (GFC) from 2001 to 2017 (Hansen et al. 2013). Natural forest comprised old-growth forest that had not been completely cleared in the last thirty years (Margono et al. 2014). We note that GFC database also provides forest cover data for 2000, but this data includes timber plantation estates (Margono et al. 2014). The algorithm used for generating forest loss in the GFC dataset differs between the 2000-2010 and 2011-2017 time periods (https://earthenginepartners.appspot.com/science-2013-global-forest/download_v1.7.html). Improved detection of selective logging in the 2011-2017 algorithm suggests that fine-scale logging activities are likely to be better captured in the later period than in the earlier one. The natural forest data for 2000 and the GFC dataset both have pixel size of $30 \mathrm{~m}$. Forest degradation was then obtained by aggregating the $30 \mathrm{~m}$ forest pixels to $125 \mathrm{~m}$ resolution map. Intact forest was defined as cell with forest cover $\geq 60 \%$ and degraded land with forest cover $<60 \%$. We overlaid data on soil type and forest degradation to obtain $125 \mathrm{~m}$ resolution maps of land types every year between 2001 and 2017 (Table S2). These maps comprise four classes: (1) intact forest on mineral soil, (2) degraded land on mineral soil, (3) intact peat forest, and (4) degraded peatland. 


\subsubsection{Village primary livelihoods}

Primary livelihoods sectors across villages in Kalimantan were derived by overlaying: (1) data on the livelihoods of the majority of people at village level (or the livelihood sectors that primarily drive the village economy) obtained from the Potensi Desa (PODES, 'Village Potential') dataset (BPS 2017), and (2) data on agro-industrial and forest concessions (Santika et al. 2015, 2020; Gaveau et al. 2016).

PODES data are collected from village heads by the Central Bureau of Statistics (BPS) Indonesia roughly every 3 years between 2000 and 2014 (i.e. 2000, 2003, 2005, 2008, 2011 and 2014), and contain information on the socioeconomic and development status for each village administrative boundary or polygon. Four major livelihoods were identified via PODES: (1) subsistence production (i.e. swidden rice agriculture on dryland, and freshwater fishing, and typically supplemented by forest product collection in complex agroforestry landscapes), (2) agricultural plantations (cash crops, e.g. rubber, oil palm, coffee, and coconut, and either independent smallholder plantations in simple agroforestry landscapes and industrial-scale monocultural plantations), (3) forestry (mainly logging concessions and timber plantations), and (4) other sectors, which include horticulture, aquaculture, coastal fisheries, livestock, and non-agricultural activities. Between 2000 and 2014, the boundaries of villages had changed overtime in the PODES dataset, as some villages were divided to account for demographic changes (known as pemekaran desa). To allow comparison of village primary livelihood changes through time, we used village boundaries based on Population Census 2010 (BPS 2010) as a reference, and then adjusted the primary livelihood variable by recalculating the original PODES data to match the Census 2010 boundaries. For example, village boundaries in the PODES 2008 and 2011 largely correspond to Census 2010 village boundaries, thus data on primary livelihoods from these PODES censuses could be straightforwardly matched to the village reference boundaries. Some villages in PODES 2000, 2003 and 2005, on the other hand, could encompass two or more village boundaries in Census 2010 due to the splitting of the old village administrative unit. Therefore, the primary livelihoods in the reference boundaries were estimated as the primary livelihoods recorded in the older village administrative unit. Conversely, several villages in PODES 2014 could be encapsulated within the boundaries of a village in Census 2010. Therefore, the primary livelihoods in the reference boundaries were estimated as the majority of livelihoods of villages contained within the reference boundaries or the livelihoods of village with the largest populations. We note that some villages have administrative boundaries that encompass conservation zones (e.g. national parks) defined by the MEF, although people are not permitted to actually reside in these zones.

Concession data include logging concessions on natural forest, timber plantation concessions, and oilpalm concessions (Santika et al. 2015; Gaveau et al. 2016). To reduce uncertainty regarding the official and the actual status of concession ownership, we included only the actively managed concessions in our evaluation. Data about the management status of logging concessions and timber plantations concessions in villages between 2000 and 2015 was gathered from scientific literature, online reports published by the MEF and concessions companies, and local newspaper articles, through manual search for each concession name and accompanied by the name of villages or districts in which this concession was located. For the oil-palm 
concessions, we selected only those in which some of the area had already been planted with oil palm, as proxy for active management. To do so, we overlaid the oil-palm concession data with the distribution of planted oilpalm plantations every three years between 2000 and 2017 provided by Santika et al. (2019a, b, 2020). It is worth noting that the concession dataset may not contain the full list of permits for all agro-industrial and forest concessions. This is due to difficulties in assembling concession permits and boundaries that are documented across different government institutions and levels of authorities. Nonetheless, the data represents the best information available about the distributions of the majority of concessions across Kalimantan.

Village livelihood data from PODES censuses were available for 2000, 2003, 2005, 2008, 2011 and 2014. We assumed that village livelihoods in any year between 2000 and 20017 outside these census years are the same as those in the preceding census (Table S2). Data on active agro-industrial and forest concessions were also available only for 2000, 2005, 2010 and 2015. We assumed that active concessions in any year between 2000 and 2017 outside these years are the same as those in the preceding year (Table S2). We combined information on livelihoods and concession types to obtain seven nuanced village primary sectors across Kalimantan every year between 2002 and 2017 (Table S2): (1) subsistence livelihoods outside any concessions (SL), (2) agroforestry and polyculture plantations outside any concessions (mainly includes independent smallholder plantations and smaller proportion of medium to large-scale industrial plantations without known concession permits; PL), (3) other agricultural sectors, including horticulture, aquaculture, coastal fisheries, and livestock, outside any concessions (OA), (4) subsistence livelihoods within logging concessions on natural forest land (SLLC), (5) forestry within timber plantation concessions (FRTC), (6) subsistence livelihoods within oil-palm concessions (SLOC), and (7) plantations and other agricultural sectors within oilpalm concessions (PLOC).

Villages with livelihood category SL are those that reported subsistence livelihoods as the primary sector in the PODES census and the village land area had no, or little ( $\leq 5 \%$ of the village land area), overlap with any concession boundaries. These villages are dominated by swidden farmers, animal hunting, and freshwater fishing communities, with no or very little employment in logging or plantation industry. Villages with livelihood category PL are those that reported plantations as the primary sector in the PODES census and the village land area had no, or little $(\leq 5 \%)$, overlap with any concession boundary. These villages are dominated by agroforestry farmers, independent smallholder plantations and smaller proportion of medium to large-scale industrial plantations without known concession permits. Villages with livelihood category $0 \mathrm{~A}$ are those that reported horticulture, aquaculture, coastal fisheries, livestock, and non-agricultural activities as the primary sector, and the village land area had no, or little $(\leq 5 \%)$, overlap with any concession boundaries. Villages with livelihood category SLLC are those that reported subsistence livelihoods as the primary sector and $>5 \%$ of the village land area overlapped with logging concessions on natural forest. These villages are presumed to be dominated by subsistence-based communities, but some communities are also involved in logging-related employment. Villages with livelihood category FRTC are those in which forestry was the primary sector and $>5 \%$ of the land area overlapped with timber plantation concessions. These villages are dominated by communities 
working in timber plantation industry. Villages with livelihood category SLOC are those that reported subsistence livelihoods as the primary sector and $>5 \%$ of the village land area overlapped with planted oil-palm concessions. These villages are presumed to be dominated by subsistence-based communities, but some communities are also involved in oil-palm plantation employments. Villages with livelihood category PLOC are those that reported plantations as the primary sector in the PODES census and $>5 \%$ of the land area overlapped with planted oilpalm concessions. These villages are dominated by monoculture oil-palm plantation communities.

\subsection{Data analysis}

\subsubsection{Fire spatiotemporal pattern}

We performed four types of analyses to assess fire occurrence patterns: (1) across different climate regimes; (2) across different climate regimes and land types; (3) across different climate regimes and village primary livelihoods; and lastly, (4) across different climate regimes, land types, and village primary livelihood sectors. This sequence of analyses was conducted to demonstrate how patterns of fire occurrence can be inferred differently depending on the variables included as predictors (or considered to be driving variations). This may also reflect how the pattern of fires can be interpreted differently by different stakeholders or communities in different regions and years, depending on the contexts highly relevant to that region. We expect that insights about the pattern of fire occurrence improve as more variables are taken into consideration (or increased level of complexity). Thus, while analyses 1-3 provide useful insights about fire occurrence patterns, analysis 4 provide the most comprehensive picture about the spatial and temporal variability of fires. We conducted the data analyses via two approaches: (1) exploratory method (visualization of data to discover patterns), and (2) statistical method (formal modelling and hypothesis testing to verify data patterns).

The analysis of fire occurrences across different climate regimes (analysis 1) was performed over Kalimantan. The analysis was conducted by visually assessing the relationship between the average monthly total of $\left(1 \times 1 \mathrm{~km}^{2}\right)$ fire grid-cells during the driest period across Kalimantan (i.e. $\left.\bar{F} / R E_{k}\right)$ and climate conditions across the island with the average monthly precipitation during the driest period as proxy (i.e. $\bar{R} A / N_{k}$ ), for each year $k$ between 2002 and 2017 (16 years). The driest period each year occurs from May to October (Fig. 1b). Variable $\bar{F} I R E_{k}$ was calculated from 531000 grid-cells of MODIS fire data and variable $\bar{R} A I N_{k}$ was calculated from 21200 pixels of CHIRPS dataset across Kalimantan each year. To verify the strength of this relationship, we fitted a loglevel regression model to the data (log transformation applied to the dependent variable), i.e.

$$
\log \left(\bar{F} I R E_{k}\right)=\alpha_{0}+\alpha_{1} \bar{R} A / N_{k}
$$

where $k \in\{2002,2003, \ldots, 2017\}$ and data size $n=16$. The model was fitted separately for fire with $F R P \geq 1 M W$ (all fires) and $\mathrm{FRP} \geq 100 \mathrm{MW}$ (high intensity fires) (Table S3). 
The analyses of fire occurrences across different climate regimes and land types (analysis 2) was conducted by visually assessing the relationship between the average monthly density of fire grid-cells per 100 $\mathrm{km}^{2}$ of land type category / during the driest period (i.e. $\hat{F} I R E_{k l}$ ) and climate conditions across the island with the average monthly precipitation during the driest period as proxy (i.e. $\bar{R} A / N_{k}$ ) for each year $k$ between 2002 and 2017 (16 years). Variable $\hat{F} I R E_{k l}$ was extracted from an average of 65618 grid-cells of MODIS fire data for degraded peatland, 42749 grid-cells for intact peat forest, 193524 grid-cells for degraded land on mineral soil, and 229109 grid-cells for intact forest on mineral soil (see Fig. S3 for temporal variation in the total number of grid-cells covered between 2002 and 2017 for each land type), whereas variable $\bar{R} A / N_{k}$ was extracted from 21200 pixels of CHIRPS dataset across Kalimantan each year. To verify the strength of this relationship, we fitted a log-level regression model to the data (log transformation applied to the dependent variable), i.e.

$$
\log \left(\hat{F} I R E_{k l}\right)=\beta_{0}+\beta_{1} \bar{R} A I N_{k}+\beta_{2} L T Y P E_{I}
$$

where $k \in\{2002,2003, \ldots, 2017\}$ and $/ \in\{$ intact forest on mineral soil, degraded land on mineral soil, intact peat forest, degraded peatland\}, and data size $n=64$ (4 land types over 16 years) (Table S4).

The analyses of fire occurrences across different climate regimes and village primary livelihoods (analysis 3) and across different climate regimes, land types, and village primary livelihood sectors (analysis 4) were performed at village boundaries according to the Population Census in 2010 (BPS 2010). This comprised 6621 villages across Kalimantan, with the village average size of $80 \mathrm{~km}^{2}$. For each village polygon $m$ and year $k$ between 2002 and 2017, we calculated the average monthly density of fire grid-cells during the driest period (continuous variable $F I R E_{m k}$ ), the majority of land type within the village boundaries (categorical variable $L T Y P E_{m k}$ with four classes; extracted from the land type data), and village primary livelihood sectors (categorical variable $L V H D_{m k}$ with seven classes). Additionally, we assigned climate conditions across Kalimantan each year according to the average monthly precipitation during the driest period occurring on that year (categorical variable CLIM with three classes).

The analyses of fire occurrences across different climate regimes and village primary livelihoods (analysis 3) was conducted by visually assessing the density of fire grid-cells at village level during the driest period (i.e. $\breve{F} / R E_{m k}$ ) for each category of village livelihoods (i.e. $L V H D_{m k}$ ) and climate conditions $\left(C L I M_{k}\right)$. The analyses of fire occurrences across different climate regimes, land types, and village primary livelihoods (analysis 4) was conducted by visually assessing the density of fire grid-cells at village level during the driest period (i.e. $\left.\breve{F} I R E_{m k}\right)$ for each category of village livelihoods (i.e. $L V H D_{m k}$ ), land types ( $L T Y P E_{m k}$ ), and climate conditions $\left(C L I M_{k}\right)$. To assess the significance of the effect of each village livelihood category on fire occurrence, we fitted an ordinary linear regression model to the data, i.e.

$$
\breve{F} I R E_{m k}=\delta_{0}+\delta_{1} L V H D_{m k}
$$

for each category of climate conditions (CLIM) and land types (LTYPE). The size of the data or the number of villages included in each regression model is provided in Table S5. 


\subsubsection{Priority areas for fire mitigation}

We determined priority areas for fire mitigation measures by ranking villages based on historical fire occurrence. The objective of our prioritization was to identify a portfolio of villages that, for a constrained budget, would maximise the total reduction in social, health, and environmental impacts of fire, given the assumption of successful fire prevention and management in the identified villages. The social, health and environmental impacts of fire associated with each village $m$ were measured mainly based on the total FRP values of the MODIS dataset observed within the village boundaries, i.e. FRP $P_{m}$. We used the FRP values because it is proportional to aerosol and particulate matter pollution (Christian et al. 2007; Freeborn et al. 2008; Parker et al. 2016; Mota \& Wooster 2018). Budgetary constraint is mainly related to support for immediate fire mitigation, i.e. fire prevention (awareness campaign, monitoring and law enforcement of fire ban) and fighting (human resources and tools) for the identified villages (Medrilzam et al. 2017). To limit the budgetary requirement, we limited the portfolio to 300 villages. The decision problem can therefore be formulated as

$$
\max \sum_{m=1}^{6621}\left(F R P_{m} \cdot X_{m}\right) \text { subject to } \sum_{m=1}^{6621} X_{m} \leq 300
$$

where $X_{m}$ denotes a binary control variable indicating whether or not village $m$ is selected as the priority villages. 


\section{Results and discussion}

\subsection{Fire spatiotemporal pattern}

\subsubsection{Fire occurrence across climate}

Between 2002 and 2017, mean monthly precipitation during the driest quarter (August-October) and the previous quarter (May-July) each year in Kalimantan varied considerably (Fig. 1b and Fig. S1). Based on the percentile scores, precipitation patterns can be categorized into three conditions: (1) dry years $\left(<25^{\text {th }}\right.$ percentile or <200 mm/month), which coincided with El Niño events, including 2002, 2004, 2006, 2009, and 2015 (US Climate Prediction Center 2018), (2) semi-dry years (25 $-75^{\text {th }}$ percentile or $\left.200-250 \mathrm{~mm} / \mathrm{month}\right)$, including 2003, 2005, 2011, 2012, 2013, and 2014, and (3) wet years (>75 percentile or $>250 \mathrm{~mm} / \mathrm{month}$ ), which coincided with La Niña events, including 2007, 2008, 2010, 2016, and 2017 (US Climate Prediction Center 2018). The driest year in this period was 2015, while the following years of 2016 and 2017 were the second and third wettest.

The decrease in mean monthly precipitation during the driest quarter (August-October) and the previous quarter (May-July) in a given year was correlated with an exponential increase in fire occurrence per month during the driest quarter (August-October) in that year (log-level regression fit; $R^{2}=0.91, p<0.001, n=16$; Fig. $2 a$ and Table S3). During wet years the mean total number of $1 \times 1 \mathrm{~km}^{2}$ grid-cells with fire detected per month was 1500 across Kalimantan (95\% confidence interval (CI) 500-3000). During semi-dry years the occurrence of fire per month reached 5000 on average (95\% Cl 4000-6000), and during dry years fire occurrence reached 12000 on average (95\% Cl 10000-15000).

Fires that occurred in Kalimantan during the driest quarter in any year were largely low-intensity $(\mathrm{FRP}<100 \mathrm{MW})$, and this was likely associated with the widespread use of fire by small farmers for land preparation prior to planting of crops and the low-intensity smouldering fires on peatland (Ichoku et al. 2008; Vadrevu et al. 2013; Liu et al. 2015). The decrease in mean monthly precipitation during the driest quarter (August-October) and the previous quarter (May-July) in a given year was correlated with an exponential increase in higher-intensity fires ( $F R P \geq 100 \mathrm{MW}$ ) per month during the driest quarter (August-October) in that year (log-level regression fit; $R^{2}=0.89, p<0.001, n=16$; Fig. $2 b$ and Table S3). The number of $1 \times 1 \mathrm{~km}^{2}$ gridcells with higher-intensity fires per month across Kalimantan was 300 during wet years (95\% Cl 2-650), but during semi-dry years the number was up to four times higher (1200 on average; 95\% Cl 850-1500), and during dry years the number was up to ten times higher (3500 on average; 95\% Cl 2500-4500). Hence, El Niño dry years have profound impact on amplifying the occurrence of all fires and high intensity fires. 


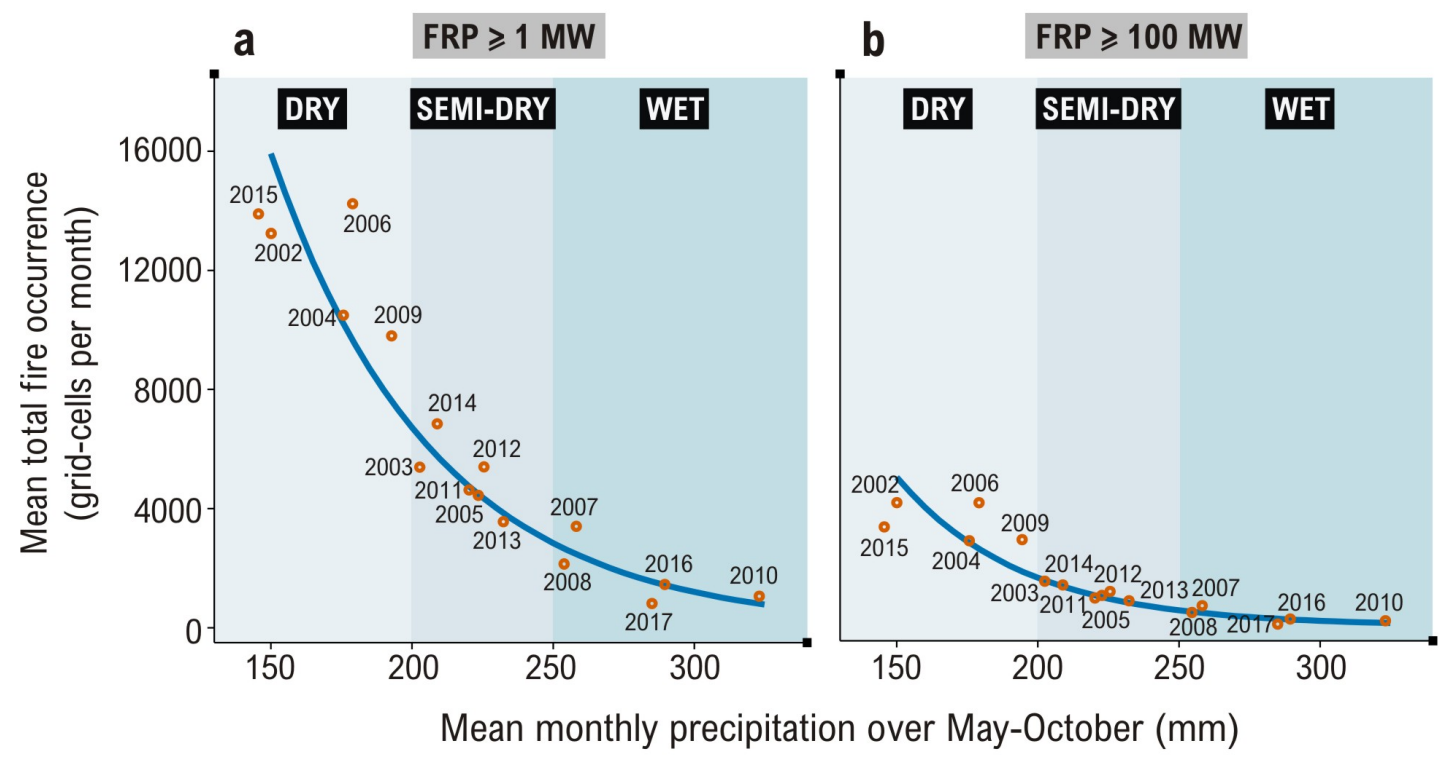

Fig. 2. Fire occurrence in relation to climate. The relationship between the mean total number of $1 \times 1 \mathrm{~km}^{2} \mathrm{grid}$-cells with fire of varying intensities detected by MODIS: (a) Fire Radiative Power (FRP) $\geq 1 \mathrm{MW}$ or all fires, and (b) FRP $\geq 100 \mathrm{MW}$ or higher intensity fires, per month across Kalimantan, and the mean monthly precipitation condition over May-October in any given year: dry (precipitation <200 mm/month), semi-dry (precipitation 200-250 mm/month), and wet years (precipitation $>250 \mathrm{~mm} / \mathrm{month}$ ). Blue line denotes the fitted exponential regression line of the total fire occurrence ( $y$-axis) on the mean monthly precipitation amount over May-October ( $x$-axis) (log-level regression fit; $R^{2}$ $=0.91$ for FRP $\geq 1 \mathrm{MW}$ and $\mathrm{R}^{2}=0.89$ for FRP $\geq 100 \mathrm{MW}, \mathrm{p}<0.001, n=16$; see Table S3 for detail estimation).

\subsubsection{Fire occurrence across climate and land types}

The relationship between the decrease in mean monthly precipitation during the driest quarter (August-October) and the previous quarter (May-July) in a given year and the exponential increase in fire occurrence per month during the driest quarter (August-October) in that year varied significantly by land type (log-level regression fit; $\mathrm{R}^{2}=0.88, p<0.001, n=64$; Fig. 3 and Table S4). During wet years, the occurrence of low or high intensity fires during the driest quarter (August-October) was similar across the different land types. During semi-dry years, however, fire occurrence varied with land types, and during dry years the difference among land types was substantial. Degraded peatland was extremely vulnerable to fire amplification with reduced rainfall, with monthly fire density had an average of 2 (95\% Cl 1-3) grid-cells per $100 \mathrm{~km}^{2}$ during semi-dry years and reached 7 (95\% Cl 5-9) grid-cells per $100 \mathrm{~km}^{2}$ during dry years (Fig. 3a). Comparatively, intact peat forest had significantly lower monthly fire density during dry years with an average of 2 (95\% Cl 1-4) grid-cells per $100 \mathrm{~km}^{2}$ (Fig. 3a). Intact forest and degraded land on mineral soil also had significantly lower monthly fire density during dry years, with an average of less than 1 grid-cells and 2 (95\% Cl 1-4) grid-cells per $100 \mathrm{~km}^{2}$, respectively (Fig. 3b). 


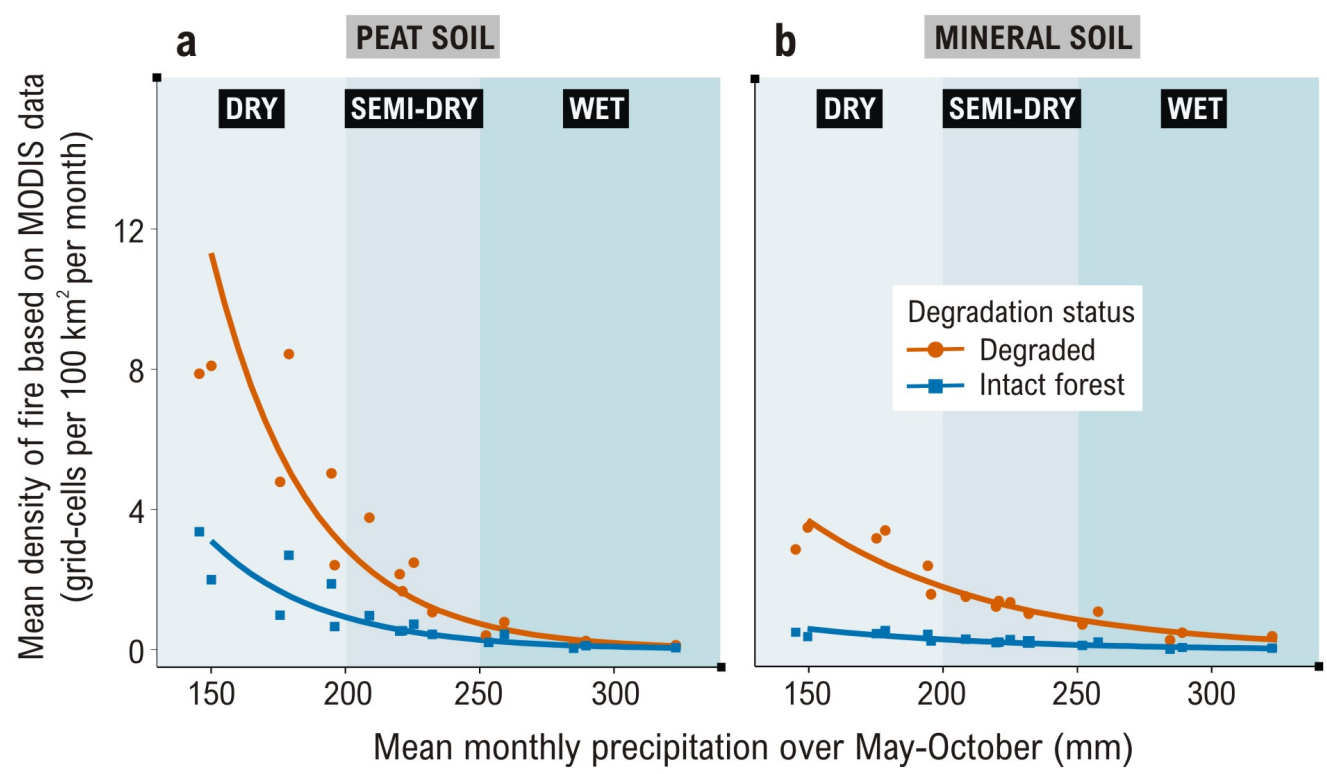

Fig. 3. Fire occurrence in relation to climate and land type. The relationship between the mean density of fire gridcells per $100 \mathrm{~km}^{2}$ per month across Kalimantan detected by MODIS on (a) peat soil and (b) mineral soil, by mean monthly precipitation condition over May-October in any given year: dry (precipitation $<200 \mathrm{~mm} / \mathrm{month}$ ), semi-dry (precipitation 200-250 mm/month), and wet years (precipitation $>250 \mathrm{~mm} / \mathrm{month}$ ). The line denotes the fitted exponential regression line of the density of fire ( $y$-axis) on the mean monthly precipitation amount over May-October ( $x$-axis) (log-level regression fit; $R^{2}=0.88, p<0.001, n=64$; See Table $S 4$ for detail estimation).

A similar pattern of fire occurrence is apparent from the VIIRS data, but with significantly higher fire detections for degraded land (both on peat and mineral soil) during semi-dry and dry years compared to those generated by the MODIS data due to improved spatial resolution of VIIRS (Fig. S4). Our results corroborate previous studies suggesting that deforestation and degradation on peatland have a much more profound impact on escalating fire risk during dry years than deforestation occurring on mineral soil, mainly because of the escalated likelihood of escaped fire due to the draining of peatland in dry years (Page \& Hooijer 2016; Taufik et al. 2017).

\subsubsection{Fire occurrence across climate and village livelihoods}

Village primary livelihoods in Kalimantan tend to be concentrated in some regions more than others, following the main biophysical conditions present. Based on 2014 data, villages with primary livelihoods subsistence production within logging concessions on natural forest (livelihood category SLLC) are most prevalent in the hilly and mountainous (>500 $\mathrm{m}$ a.s.l) interior parts of the island, where old growth forest currently remains, largely located in the province of North Kalimantan, followed by East and Central Kalimantan (Fig. 4a). Villages with primary livelihoods plantations outside any concessions (PL) are most prevalent in the lowlands of West Kalimantan, followed by Central Kalimantan (Fig. 4a). Villages coinciding with monoculture agro-industrial concessions (oil palm or timber) (PLOC, SLOC and FRTC) are most prevalent in the lowlands of Central 
Kalimantan, followed by West Kalimantan (Fig. 4a). Between 2002 and 2017, substantial change in primary livelihoods sectors had occurred across Kalimantan villages (Fig. 4b). The proportions of villages with subsistence-based livelihoods outside any concessions (SL) and subsistence livelihoods within the boundaries of logging concessions on natural forest (SLLC) had reduced. Conversely, villages with plantation sectors, either those predominated by smallholders $(\mathrm{PL})$ or large-scale monoculture oil palm plantations (PLOC), had increased from $10 \%$ to $30 \%$ over the last 15 years.

The spatial distribution of fire occurrence in different climate regimes (wet, semi-dry and dry years) is associated with different livelihood sectors, and this is related to the interaction between different levels of agricultural activities and soil-degradation-induced fire risk. During wet years, fires are typically less common (Fig. 5a), as heavy rains have an adverse effect on agricultural activities, especially on secondary crops and horticulture (Boissière et al. 2013; Midmore 2015), and the spread of fire is less likely to occur with more precipitation and lower flammability (Taufik et al. 2017). Heavy rainfall can also result in flooding particularly in lowlands, resulting in markedly reduced agriculture productivity (Boissière et al. 2013). During these heavy rainfall years, fire occurrences mostly occur in villages outside concessions where subsistence livelihoods (SL) and polyculture plantation smallholders (PL) dominate (Fig. 5d). These villages are largely located in West Kalimantan province (Fig. 5g), and practice non- and semi-commercial agricultural activities, in remote areas with moderate forest cover (40-50\%), and largely on mineral soil (Fig. S5).

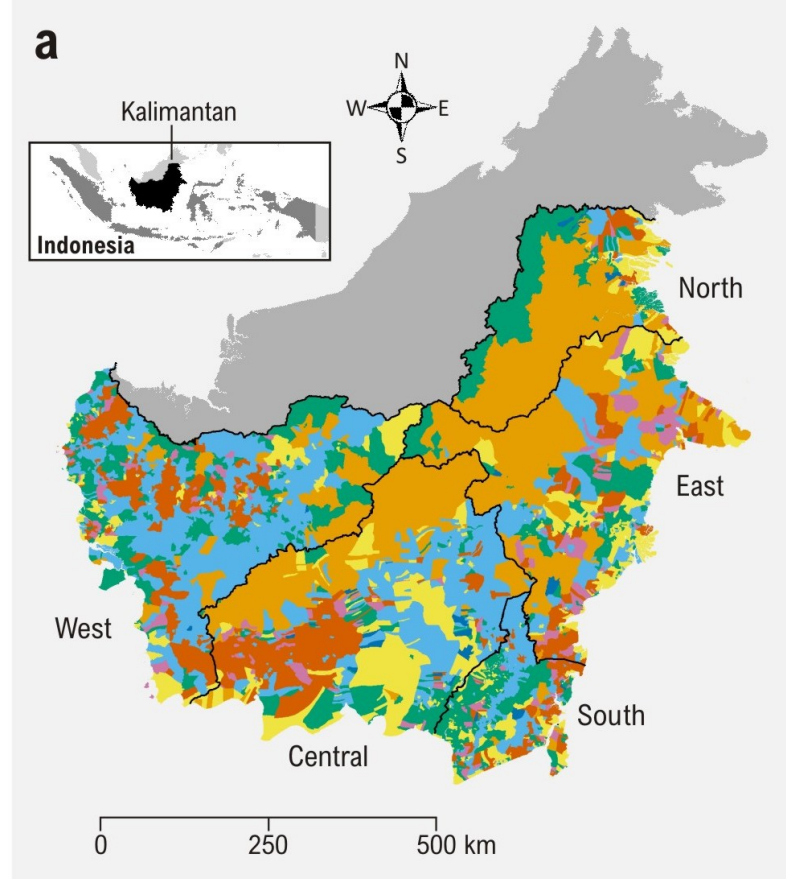

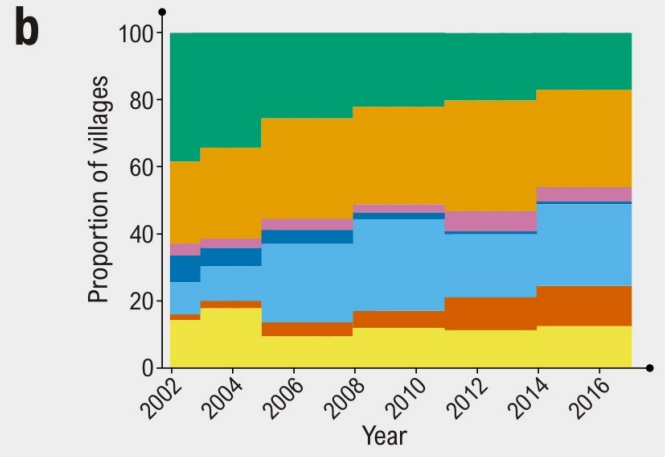

VILLAGE PRIMARY LIVELIHOOD SECTOR

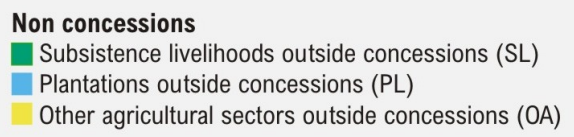

Other agricultural sectors outside concessions (OA)

Concessions

Subsistence livelihoods within logging concessions on natural forest (SLLC)

Forestry sector within timber plantation concessions (FRTC)

Subsistence livelihoods within oil palm concessions (SLOC)

Plantations and other agricultural sectors within oil palm concessions (PLOC)

Fig. 4. Village primary livelihood sectors in Kalimantan. (a) Spatial distributions of village primary livelihoods in Kalimantan circa 2014, and (b) the change in the proportion of villages with different primary livelihood sectors across the island between 2002 and 2017. 


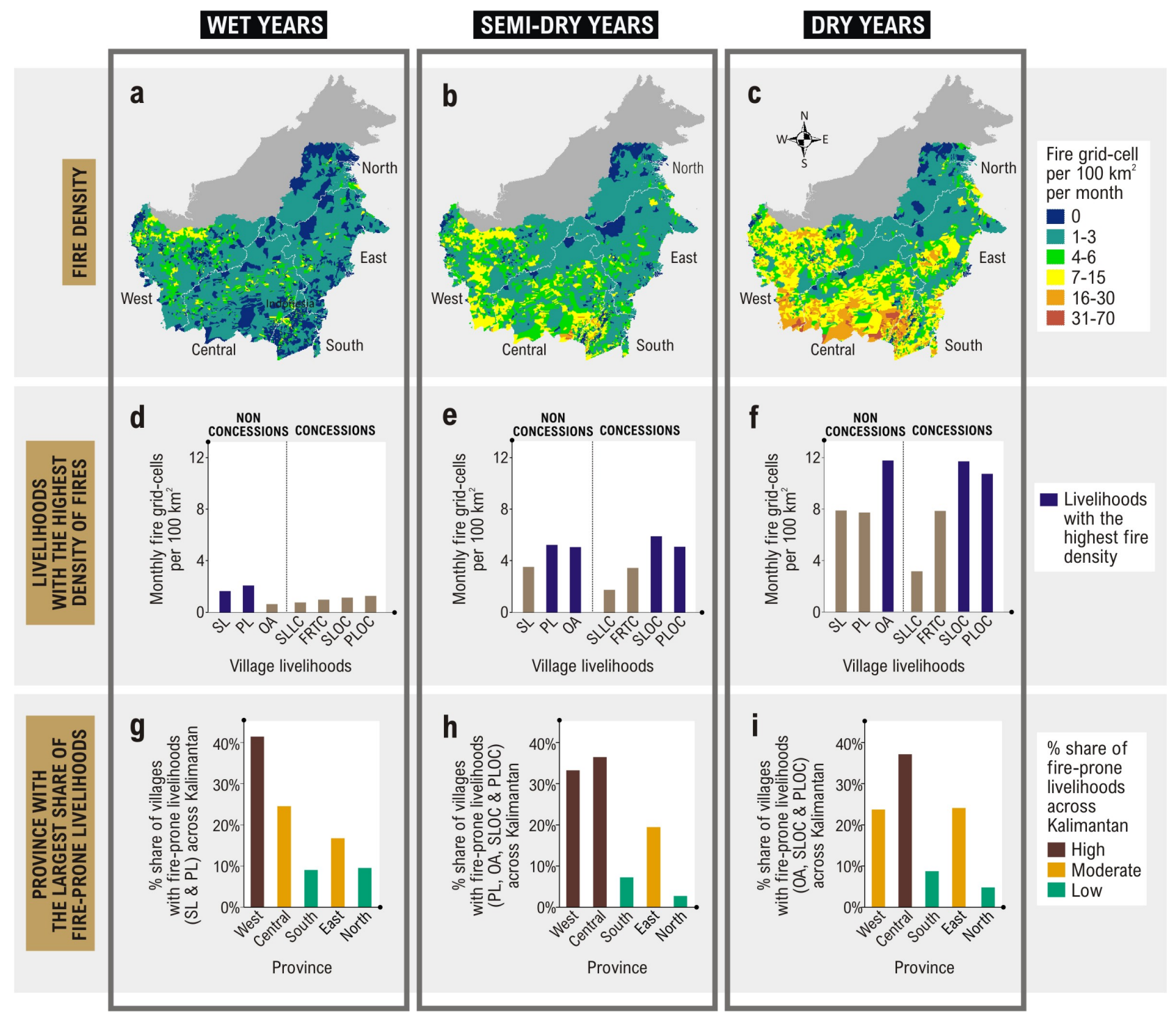

Fig. 5. Fire distributions in relation to climate and village livelihood sectors. (a-c) Density of $1 \times 1 \mathrm{~km}^{2}$ grid-cells with fires per village per month, $(d-f)$ livelihood sectors with the highest density of fires, and $(g-i)$ province with the largest share of fire-prone livelihoods, by precipitation condition over May-0ctober in any given year: wet (precipitation >250 $\mathrm{mm} /$ month, occurred in 2007, 2008, 2010, 2016, and 2017), semi-dry (precipitation 200-250 mm/month, occurred in 2003, 2005, 2011, 2012, 2013, and 2014), and dry years (precipitation <200 mm/month, occurred in 2002, 2004, 2006, 2009, and 2015). Cut-off thresholds for defining high (>25\%), moderate (10-25\%), and low (<10\%) share of fire prone livelihoods within province in panel $(g-i)$ were based on percentile scores (i.e. $33^{\text {rd }}$ and $66^{\text {th }}$ percentile). Livelihood sectors include: SL=subsistence livelihoods outside any concessions, PL=agroforestry and polyculture plantations outside any concessions, $\mathrm{OA}=0$ ther agricultural sectors outside any concessions (e.g. horticulture, aquaculture, coastal fisheries, and livestock), SLLC=subsistence livelihoods within logging concessions on natural forest, FRTC=forestry within timber plantation concessions, SLOC=subsistence livelihoods within oil-palm concessions, and PLOC=plantations and other agricultural sectors within oil-palm concessions. 
Semi-dry years are favourable for agricultural activities, and fires are more common (Fig. 5b). During semi-dry years fires mostly occur in villages outside concessions where polyculture plantation smallholders (PL) and other agricultural sectors $(\mathrm{OA})$ dominate, and in villages coinciding with industrial oil palm concessions where communities rely on subsistence livelihoods (SLOC) or plantations or other agricultural sectors (PLOC) (Fig. 5e). These villages are largely located in West and Central Kalimantan provinces (Fig. 5h), and practice semi- and fully-commercial agricultural activities, in more accessible areas with low to moderate forest cover (10-40\%), and larger proportions on peat soil (Fig. S5).

During dry years, fires are widespread (Fig. 5c), as conditions are optimal for clearing land in preparation for agricultural activities (although not necessarily good for growing crops), and the risk of uncontrolled fires is amplified especially in areas with severe dryness (Taufik et al. 2017). During dry years fires mostly occur in villages outside concessions where other agricultural sectors predominate $(0 A)$ and in villages coinciding with industrial oil palm concessions (SLOC and PLOC) (Fig. 5f). These villages are largely located in Central Kalimantan province (Fig. 5I), practicing fully-commercial agricultural activities in highly accessible areas, with low to moderate forest cover (10-40\%), and larger proportions located on degraded peatland (Fig. S5). The amplification of fire occurrences during the dry years reflects the impact of increased fuel loads due to the draining of peatland.

The spatial distributions of fires in Kalimantan, therefore, tend to concentrate in different regions predominated by specific livelihood sectors, in different years with different climate conditions. Thus, focussing on the occurrence of fire (or fire hotspots) in a specific year without sufficient knowledge of fire spatiotemporal variability can potentially lead to misleading inference about the livelihood sector that are mainly responsible for catastrophic fire (Fig. 5 and Fig. S6). For example, villages with subsistence (swidden) farmers (SL) and polyculture plantation smallholders (PL) indeed have the highest hotspot density during wet and semi-dry years (Fig. S6), but these fires are mild overall and occur primarily on mineral soil.

\subsubsection{Fire occurrence across climate, land types and village livelihoods}

By accounting for the variability in climate, land types, and village livelihood sectors, we obtained a comprehensive picture about the pattern of fire occurrences across Kalimantan, and importantly the primary areas and livelihood sectors with the highest likelihood of fire occurrences. In degraded peatland, the occurrence of fire is typically higher during semi-dry and dry years, regardless of the village primary livelihood sector (Fig. 6a). This is confirmed by the non-significant effect of all livelihood variables in Eq. 3 (Table S6; rows 8 and 12). However, in intact forest, both on peat and mineral soil, the density of fires in villages that largely coincide with oil palm concessions (SLOC and PLOC) is twice as high as in villages outside oil palm concessions (Figs. 6b, d). This is confirmed by the significant effects of variables associated with these livelihood sectors in Eq. 3 (Table S6; rows 5, 7, 9 and 11). In degraded lands on mineral soil, villages where most people rely on subsistence livelihoods within oil palm concessions (SLOC) or those where people are reliant on forestry within timber plantation concessions (FRTC), also have fire density twice as high as in other villages (Fig. 6c). This is 
also confirmed by the significant effects of variables associated with SLOC and FRTC in Eq. 3 (Table S6; row 10). A similar pattern of fire occurrences was evident from VIIRS data, but with higher detections of fire during dry years (Fig. S7). The higher prevalence of fire in villages coincide with the industrial-scale plantation concessions in intact forest and degraded lands on mineral soil can be driven by various reasons, including the use of fire for forest and land clearing by companies or small farmers (Purnomo et al. 2017) and as a weapon to prevent access or damage crops in conflicts related to land tenure between companies and local communities (Herawati \& Santoso 2011).
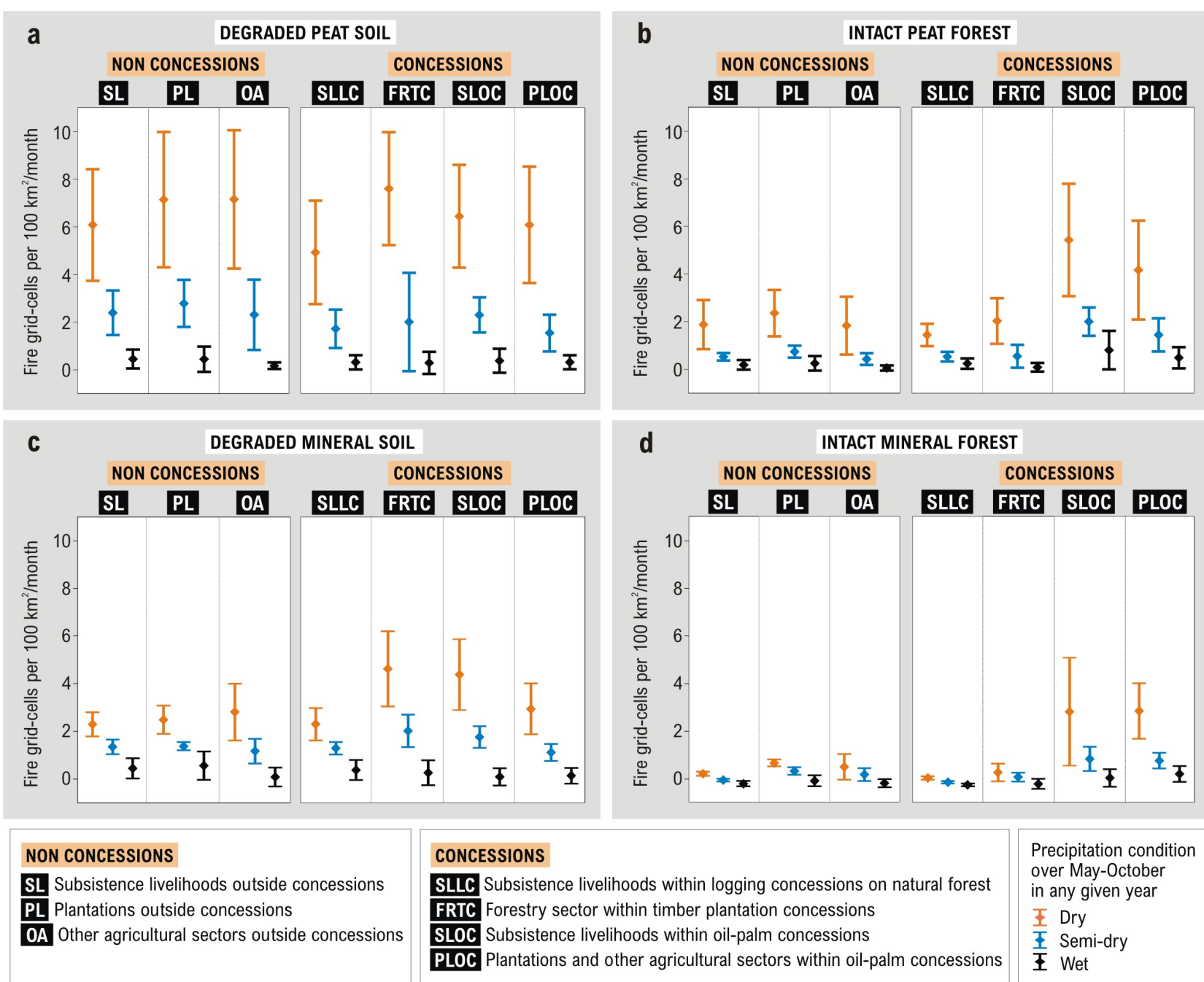

Precipitation condition over May-October in any given year I Dry 王 Semi-dry 王 Wet

Fig. 6. Density of fires in relation to climate, land type and village livelihoods. Density of $1 \times 1 \mathrm{~km}^{2}$ grid-cells with fires per $100 \mathrm{~km}^{2}$ per month across different village livelihood sectors in (a) degraded peat soil, (b) intact peat forest, (c) degraded land on mineral soil, and (d) intact forest on mineral soil, by precipitation condition over May-October in any given year: dry (precipitation <200 mm/month), semi-dry (precipitation 200-250 mm/month), and wet (precipitation $>250 \mathrm{~mm} / \mathrm{month}$ ). 
A potential caveat to our findings is that we conducted the analysis based on the occurrence of fire derived from MODIS and VIIRS active fire products. While relatively high intensity fires can be accurately detected via these datasets, cooler or smouldering fires, especially those commonly occur on degraded peatland may be more difficult to detect (Atwood et al. 2016). A recent study has shown that VIIRS fire product has the accuracy of detecting the actual smouldering on peatland of $71 \%$ (Sofan et al. 2019), suggesting that about a third of the actual smouldering events were potentially overlooked. MODIS fire product likely has lower detection accuracy than VIIRS data for smouldering fires due to the lower spatial resolution. In addition, the characteristic of controlled versus escaped fires may be better captured by combining hotspots and burn scars data, e.g. MODIS Burned Area Product MCD64A1 (Giglio et al. 2018). Despite these limitations, our broad-scale analysis of both biophysical and social drivers of fires is of significant advance over previous studies that have so far focused either on large-scale biophysical pattern of fires or local studies of social or institutional processes of fires (Table S1).

\subsection{Priority areas for fire mitigation measures}

Our prioritization exercise focussed on fire occurrence over August-October during dry years, because the risk of fire is potentially highest during this period (Fig. 1). We also focussed on villages on peatland (regardless of primary livelihoods) and villages coinciding with industrial (timber and oil-palm) plantations (regardless of soil types), because these are the key areas and key livelihood sectors where the risk of fire escaping is highest during dry years, and in peatland fire has the greatest potential to cause widespread toxic haze (Figs. 3, 6). Although our fire typology identified areas with most fires in different climate regimes (i.e. wet, semi-dry and dry years), suggesting that it is possible to assess different priorities according to different climate conditions, this is likely to be challenging to implement in practice. The main reason is the difficulty in forecasting drought conditions early in any given year, despite advancement in weather prediction and dynamic modelling technology (Hao et al. 2018). Furthermore, climate patterns across Indonesia are expected to become more unpredictable and more variable in the future as a result of global climate change (Fischer \& Knutti 2015). Thus, management priorities based on dry years alone represent a conservative approach in preventing widespread toxic haze.

Based on MODIS data and with the above constraints, targeted intervention in 300 villages could reduce the impact of fire by $48 \%$ (assuming that fire in the targeted villages is effectively reduced to zero), with $68 \%$ of these villages located on peatland (Fig. 7). As many as 128 villages (50\%) with industrial oil-palm plantations as the primary livelihood sector (livelihood category PLOC) and 54 villages (18\%) where most communities rely on subsistence livelihoods within oil-palm concessions (SLOC) had contributed most to the detrimental impacts of fire (28\% of total fire impact, $11 \%$ of total PLOC and SLOC villages in Kalimantan). Half of these villages are located on peatland. Our priority villages also include 31 villages (10\%) outside concessions where polyculture 
plantation smallholders predominate (PL) and 26 villages (8\%) outside concessions where subsistence-based communities predominate (SL) (11\% of total fire impact, 1.7\% of total PL and SL villages in Kalimantan), and all of these villages are located on degraded peatland.

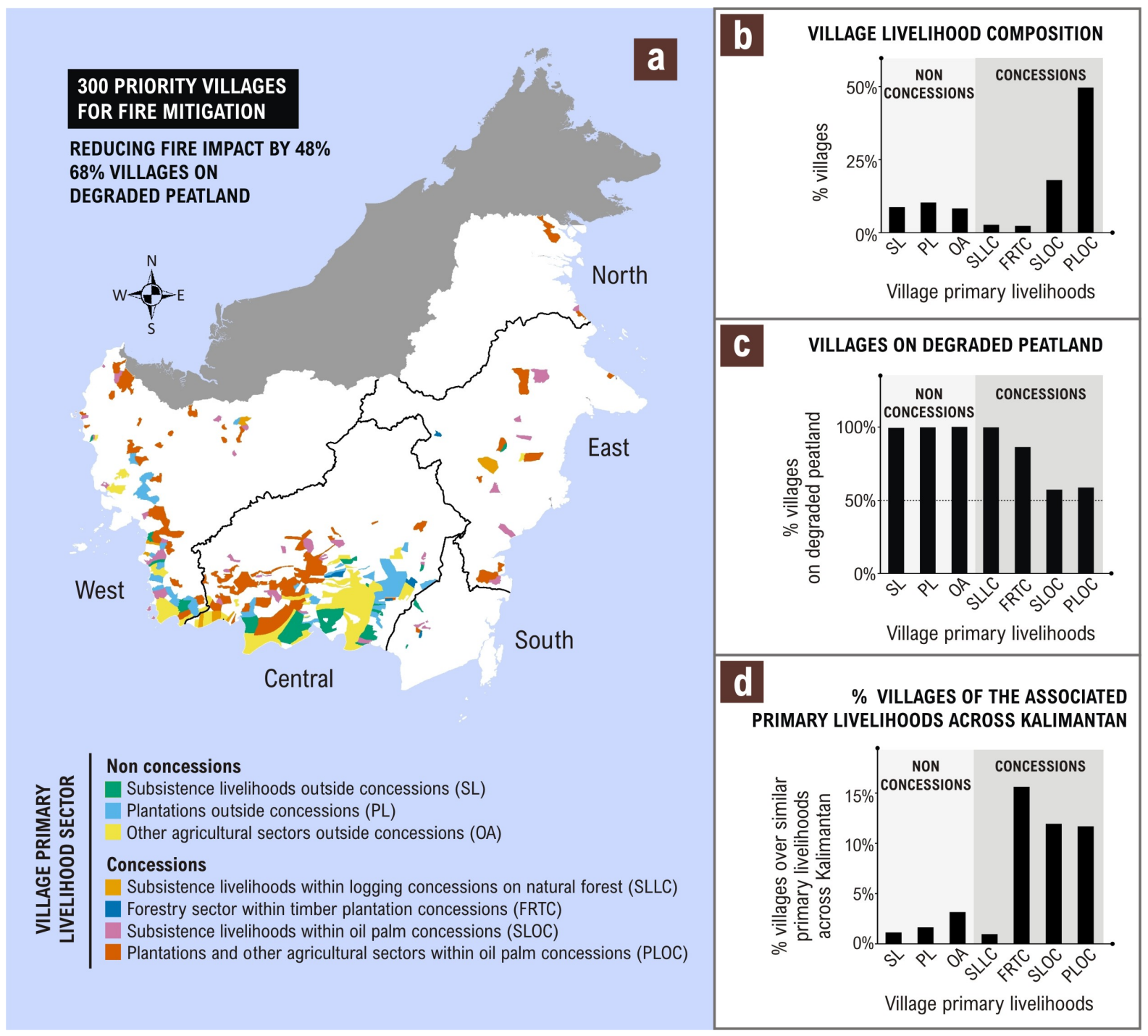

Fig. 7. Priority villages for fire mitigation. (a) 300 villages with the highest fire intensity (FRP) based on MODIS data over August-October during dry years (2002, 2004, 2006, 2009, and 2015). (b) Composition of priority villages by primary livelihood sectors, (c) percentage of villages located on degraded peatland, and (d) percent share of the priority villages over all villages with the same primary likelihoods across Kalimantan. 
The implementation of fire management in villages where subsistence farmers and smallholder plantations predominate (SL and PL) can be politically challenging and ineffective. This is due to the significant dilemma faced by the local government to impose a fire ban in recognition of the impact this may have on local food security and community coexistence, while transition towards non-fire use would require major financial and technical assistance (Mertz \& Bruun 2016; Thu et al. 2018; Thung 2018). However, our study highlights the importance of restoring peatland and mitigating fires in villages located on degraded peatland, regardless of the primary livelihood sectors, as these villages have the highest risk of escaped fires and these fires cause widespread toxic haze (Budiharta et al. 2018; Watts et al. 2019). Incentive schemes to assist smallholders in villages on peatland to comply with environmental regulations pertaining to land management without burning (Pengolahan Lahan Tanpa Bakar or PLTB) especially during the driest period (May to October), can potentially reduce fire ignitions in the short-term. A recent study from peatland landscape in Riau, Sumatra, shows that this type of incentive scheme was able to reduce the occurrence of fire in a village by $40 \%$ (Watts et al. 2019). The PLTB program also promotes transition to more sustainable livelihood activities for local communities, such as animal husbandry and floating hydroponic culture (BRG 2016).

Our prioritization approach assumes that the relationship between the FRP and particulate matter pollution are the same between peat and mineral soil. However, studies suggest that the amount of carbon monoxide and fine particulate matter emitted per dry matter burned on peatland is significantly higher compared to that on mineral soil, due to strong dominance of peat smouldering rather than flaming combustion (Christian et al. 2007; Atwood et al. 2016; Parker et al. 2016). This suggests that the social, health, and environmental impacts of fire on degraded peatland could be even greater than our estimates, and the priority villages presented in Fig. 7 could potentially undermine the allocation of investment on degraded peatland. However, our prioritization framework can be adapted as more reliable information about the relationship between FRP and particulate matter pollution becomes available. Our prioritization can also be improved by considering long-term planning horizon beyond the immediate fire prevention and fighting, particularly for villages on degraded peatland where long-term restoration and rehabilitation are vital to stop recurring fires. 


\section{Conclusion}

Across Kalimantan, fires are most common when industrial plantation concessions are present, particularly in intact forests and degraded lands on mineral soil. Thus, the role of the industry in instigating fire supports the views held by local leaders and indigenous organizations, reinforcing the overall reluctance of these local stakeholders to support fire prevention through the introduction of a zero-burning mechanism for small-scale farmers. However, in degraded peatland, where fire is most intense during dry years and receives significant attention in the media and from higher-level policymakers, fire occurrence rates are high regardless of village livelihood sectors. This supports the views held by most stakeholders, reinforcing their preference for enforcement measures across different communities, including industrial-scale plantations, smallholders, and subsistence-based farmers. These findings highlight that the generalized assumptions on the most suitable fire mitigation measures held by local leaders and those held by higher-level policymakers cannot be applied to all cases.

As such, our analysis identified two key priorities for fire mitigation going forward in Kalimantan: degraded peatland as the priority area and industrial plantations (oil palm and timber) as the priority sector. These are key priorities where the likelihood of escaped and uncontrolled fire is highest during dry years. Mitigating fire in villages on degraded peatland, regardless of primary livelihood sectors, requires not only shortterm fire prevention (e.g. through incentive schemes to assist smallholders to comply with environmental regulations) and fighting, but also importantly long-term restoration and rehabilitation of peatland ecosystem and sustainable livelihood alternatives for local communities to prevent recurring fires during El Niño dry years. For industrial plantations, regardless of soil types, fire ban, enforcement of environmental laws and policy, and monitoring and resolving tenure conflicts between plantation companies and nearby communities are warranted. The moratorium of new oil palm plantation permits for 2018-2021 (legislated in Presidential Instruction No. 8/2018) offers an excellent opportunity to resolve these land tenure issues through improved governance. Our study further underlines the importance of protecting existing peat forests from deforestation and degradation, and from conversion to large-scale agriculture.

Our priorities for fire prevention and mitigation measures explicitly accounted for the spatio-temporal heterogeneity exhibited in these fire-prone landscapes. The analysis framework we present utilized publicly available global spatio-temporal datasets (on fire occurrence, precipitation, and forest cover) and government census data (on village socioeconomic features), hence the approach has great potential to be replicated to other geographies facing similarly complex and dynamically-driven vegetation fires, such as the Brazilian Amazon, Africa, and South Asia regions. 


\section{References}

As-syakur, A.R., Tanaka, T., Osawa, T. \& Mahendra, M.S. (2013) Indonesian rainfall variability observation using TRMM multi-satellite data. International Journal of Remote Sensing 34, 7723-7738.

Atwood, E.C., Englhart, S., Lorenz, E., Halle, W., Wiedemann, W. \& Siegert, F. (2016) Detection and characterization of low temperature peat fires during the 2015 fire catastrophe in Indonesia using a new high-sensitivity fire monitoring satellite sensor (FireBird). PLoS One 11, e0159410.

Bai, L., Shi, C., Li, L., Yang, Y. \& Wu, J. (2018) Accuracy of CHIRPS satellite-rainfall products over mainland China. Remote Sensing 10, 362.

BMKG (Meteorology, Climatology, and Geophysical Agency Indonesia) (2019) Data Iklim Kalimantan. Pusat Database BMKG, Jakarta. Available at: http://dataonline.bmkg.go.id/data_iklim.

Boissière, M., Locatelli, B., Sheil, D., Padmanaba, M. \& Sadjudin, E. (2013) Local perceptions of climate variability and change in tropical forests of Papua, Indonesia. Ecology and Society 18, 13.

Badan Restorasi Gambut (BRG) (2016) Mengawali Restorasi Gambut Indonesia. Jakarta, Indonesia. Available at: https://brg.go.id/files/Publikasi/BRG\%202016\%20report_29.05.17.pdf

Budiharta, S., Meijaard, E., Gaveau, D.L.A., Struebig, M.J., Wilting, A. et al. (2018) Restoration to offset the impacts of developments at a landscape scale reveals opportunities, challenges and tough choices. Global Environmental Change 52, 152-161.

Bureau of Statistic Indonesia (BPS) (2010) Village Administrative Map - Population Census 2010. Jakarta, Indonesia.

Bureau of Statistic Indonesia (BPS) (2017) Village Potential Statistics (PODES) 2000, 2003, 2005, 2008, and 2014. Jakarta, Indonesia.

Cai, W., Santoso, A., Wang, G., Weller, E., Wu, L. et al. (2014) Increased frequency of extreme Indian Ocean Dipole events due to greenhouse warming. Nature 510, 254.

Carmenta, R., Zabala, A., Daeli, W. \& Phelps, J. (2017) Perceptions across scales of governance and the Indonesian peatland fires. Global Environmental Change 46, 50-59.

Cattau, M.E., Harrison, M.E., Shinyo, I., Tungau, S., Uriarte, M. et al. (2016) Sources of anthropogenic fire ignitions on the peat-swamp landscape in Kalimantan, Indonesia. Global Environmental Change 39, 205-219.

Christian, T.J., Yokelson, R.J., Carvalho, J.A., Griffith, D.W.T., Alvarado, E.C. et al. (2007) The tropical forest and fire emissions experiment: Trace gases emitted by smoldering logs and dung from deforestation and pasture fires in Brazil. Journal of Geophysical Research: Atmospheres 112, D18308.

Cramb, R.A., Colfer, C.J.P., Dressler, W., Laungaramsri, P., Le, Q.T., Mulyoutami, E. et al. (2009) Swidden transformations and rural livelihoods in Southeast Asia. Human Ecology 37, 323-346.

Dennis, R.A., Mayer, J., Applegate, G., Chokkalingam, U., Colfer, C.J.P. et al. (2005) Fire, people and pixels: linking social science and remote sensing to understand underlying causes and impacts of fires in Indonesia. Human Ecology 33, 465-504. 
Dinku, T., Funk, C., Peterson, P., Maidment, R., Tadesse, T., Gadain, H. et al. (2018) Validation of the CHIRPS satellite rainfall estimates over eastern Africa. Quarterly Journal of the Royal Meteorological Society 144, 292-312.

Fanin, T. \& Van der Werf, G.R. (2017) Precipitation-fire linkages in Indonesia (1997-2015). Biogeosciences 14, 3995-4008.

Field, R.D., Van Der Werf, G.R., Fanin, T., Fetzer, E.J., Fuller, R. et al. (2016) Indonesian fire activity and smoke pollution in 2015 show persistent nonlinear sensitivity to El Niño-induced drought. Proceedings of the National Academy of Sciences 113, 9204-9209.

Fischer, E.M. \& Knutti, R. (2015) Anthropogenic contribution to global occurrence of heavy-precipitation and high-temperature extremes. Nature Climate Change 5, 560.

Forsyth, T. (2014) Public concerns about transboundary haze: A comparison of Indonesia, Singapore, and Malaysia. Global Environmental Change 25, 76-86.

Fox, J., Castella, J.C. \& Ziegler, A.D. (2014) Swidden, rubber and carbon: Can REDD+ work for people and the environment in Montane Mainland Southeast Asia? Global Environmental Change 29, 318-326.

Franchito, S.H., Rao, V.B., Vasques, A.C., Santo, C.M. \& Conforte, J.C. (2009) Validation of TRMM precipitation radar monthly rainfall estimates over Brazil. Journal of Geophysical Research: Atmospheres 114, D02105.

Freeborn, P.H., Wooster, M.J., Hao, W.M., Ryan, C.A., Nordgren, B.L. et al. (2008) Relationships between energy release, fuel mass loss, and trace gas and aerosol emissions during laboratory biomass fires. Journal of Geophysical Research: Atmospheres 113, D01301.

Funk, C., Peterson, P., Landsfeld, M., Pedreros, D., Verdin, J. et al. (2015) The climate hazards infrared precipitation with stations-a new environmental record for monitoring extremes. Scientific Data 2, 121.

Gaveau, D.L., Pirard, R., Salim, M.A., Tonoto, P., Yaen, H. et al. (2017) Overlapping land claims limit the use of satellites to monitor no-deforestation commitments and no-burning compliance. Conservation Letters 10, 257-264.

Gaveau, D.L.A., Salim, M. \& Arjasakusuma, S. (2016) Deforestation and Industrial Plantations Development in Borneo. Center for International Forestry Research (CIFOR), Jakarta. Available at: https://doi.org/10.17528/CIFOR/DATA.00049.

Giglio, L. (2015) MODIS Collection 6 Active Fire Product User's Guide Revision A. Department of Geographical Sciences, University of Maryland.

Giglio, L., Boschetti, L., Roy, D.P., Humber, M.L. \& Justice, C.0. (2018) The Collection 6 MODIS burned area mapping algorithm and product. Remote Sensing of Environment 217, 72-85.

Hansen, M.C., Potapov, P.V., Moore, R., Hancher, M., Turubanova, S. et al. (2013) High-resolution global maps of 21st-century forest cover change. Science 342, 850-853.

Hao, Z., Singh, V.P. \& Xia, Y. (2018) Seasonal drought prediction: advances, challenges, and future prospects. Reviews of Geophysics 56, 108-141. 
Harrison, M.E., Page, S.E. \& Limin, S. (2009) The global impact of Indonesian forest fires. Biologist 56, 156163.

Harwell, E. (2000) Remote sensibilities: discourses of technology and the making of Indonesia's natural disaster. Development and Change 31, 307-340.

Herawati, H. \& Santoso, H. (2011) Tropical forest susceptibility to and risk of fire under changing climate: A review of fire nature, policy and institutions in Indonesia. Forest Policy and Economics 13, 227-233.

Huffman, G.J., Bolvin, D.T., Nelkin, E.J., Wolff, D.B., Adler, R.F. et al. (2007) The TRMM multisatellite precipitation analysis (TMPA): Quasi-global, multiyear, combined-sensor precipitation estimates at fine scales. Journal of Hydrometeorology 8, 38-55.

Huijnen, V., Wooster, M.J., Kaiser, J.W., Gaveau, D.L.A., Flemming, J. et al. (2016) Fire carbon emissions over maritime southeast Asia in 2015 largest since 1997. Scientific Reports 6, 26886.

Ichoku, C. \& Ellison, L. (2014) Global top-down smoke-aerosol emissions estimation using satellite fire radiative power measurements. Atmospheric Chemistry and Physics 14, 6643-6667.

Ichoku, C., Giglio, L., Wooster, M.J. \& Remer, L.A. (2008) Global characterization of biomass-burning patterns using satellite measurements of fire radiative energy. Remote Sensing of Environment 112, 2950-2962.

Liu, M., Song, Y., Yao, H., Kang, Y., Li, M. et al. (2015) Estimating emissions from agricultural fires in the North China Plain based on MODIS fire radiative power. Atmospheric Environment 112, 326-334.

Margono, B.A., Potapov, P.V., Turubanova, S., Stolle, F. \& Hansen, M.C. (2014) Primary forest cover loss in Indonesia over 2000-2012. Nature Climate Change 4, 730.

Marlier, M.E., DeFries, R.S., Kim, P.S., Koplitz, S.N., Jacob, D.J. et al. (2015) Fire emissions and regional air quality impacts from fires in oil palm, timber, and logging concessions in Indonesia. Environmental Research Letters 10, 085005.

Marlier, M.E., DeFries, R.S., Voulgarakis, A., Kinney, P.L., Randerson, J.T. et al. (2013) El Niño and health risks from landscape fire emissions in southeast Asia. Nature Climate Change 3, 131.

Medrilzam, Rahayu, N.H., Widiaryanto, P., Rosylin, L., Firdaus, R. et al. (2017) Grand Design. Pencegahan Kebakaran Hutan, Kebun dan Lahan 2017-2019. Jakarta, Indonesia: Badan Perencanaan Pembangunan Nasional (BAPPENAS).

Meijaard, E. (2018) Indonesia's fires in the 21st century: Causes, culprits, impacts, perceptions, and solutions. In: Pollution Across Borders. Transboundary Fire, Smoke and Haze in Southeast Asia (eds. Quah, E., Tan, T.S.). pp. 103-118. World Scientific Publishing, Singapore.

Mertz, 0. \& Bruun T.B. (2016) Shifting cultivation policies in Southeast Asia-Does criminalizing traditional farming practices make them go away? In: Shifting Cultivation Policy: Trying to Get It Right (ed. Cairns, M.). Oxon: Earthscan Routledge Press.

Midmore, D.J. (2015) Principles of Tropical Horticulture. CABI (Centre for Agriculture and Biosciences International).

Ministry of Environment and Forestry Indonesia (MEF) (2017) Peatland Hydrological Unit for Island of Kalimantan. Jakarta. 
Mota, B. \& Wooster, M.J. (2018) A new top-down approach for directly estimating biomass burning emissions and fuel consumption rates and totals from geostationary satellite fire radiative power (FRP). Remote Sensing of Environment 206, 45-62.

Murdiyarso, D. \& Lebel, L. (2007) Local to global perspectives on forest and land fires in Southeast Asia. Mitigation and Adaptation Strategies for Global Change 12, 3-11.

Page, S.E. \& Hooijer, A. (2016) In the line of fire: the peatlands of Southeast Asia. Philosophical Transactions of the Royal Society B: Biological Sciences 371, 20150176.

Pan, X., Chin, M., Ichoku, C.M. \& Field, R.D. (2018) Connecting Indonesian fires and drought with the type of El Niño and phase of the Indian Ocean dipole during 1979-2016. Journal of Geophysical Research: Atmospheres 123, 7974-7988.

Parker, R.J., Boesch, H., Wooster, M.J., Moore, D.P., Webb, A.J. et al. (2016) Atmospheric $\mathrm{CH}_{4}$ and $\mathrm{CO}_{2}$ enhancements and biomass burning emission ratios derived from satellite observations of the 2015 Indonesian fire plumes. Atmospheric Chemistry and Physics 16, 10111-10131.

Paredes-Trejo, F.J., Barbosa, H.A. \& Kumar, T.L. (2017) Validating CHIRPS-based satellite precipitation estimates in Northeast Brazil. Journal of Arid Environments 139, 26-40.

Permadi, D.A. \& Oanh, N.T.K. (2013) Assessment of biomass open burning emissions in Indonesia and potential climate forcing impact. Atmospheric Environment 78, 250-258.

Prakash, S. \& Gairola, R.M. (2014) Validation of TRMM-3B42 precipitation product over the tropical Indian Ocean using rain gauge data from the RAMA buoy array. Theoretical and Applied Climatology 115, 451460.

Purnomo, H., Shantiko, B., Sitorus, S., Gunawan, H., Achdiawan, R. et al. (2017) Fire economy and actor network of forest and land fires in Indonesia. Forest Policy and Economics 78, 21-31.

Riley, K., Webley, P. \& Thompson, M. (2016) Natural Hazard Uncertainty Assessment: Modeling and Decision Support. John Wiley \& Sons.

Rohadi, D. (2017) Zero-burning policy hurts small farmers-a flexible approach is needed. The Conversation. URL: https://theconversation. com/zero-burning-policy-hurts-small-farmersa-flexible-approach-isneeded-77969.

Santika, T., Law, E.A., Wilson, K.A., St. John, F.A.V., Carlson, K.M., Gibbs, H., Morgans, C.L., Ancrenaz, M., Meijaard, E. \& Struebig, M.J. (2020) Impact of palm oil sustainability certification on village well-being and poverty in Indonesia. SocArXiv. DOI: https://doi.org/10.31235/osf.io/5qk67.

Santika, T., Meijaard, E. \& Wilson, K.A. (2015) Designing multifunctional landscapes for forest conservation. Environmental Research Letters 10, 114012.

Santika, T., Wilson, K.A., Budiharta, S., Law, E.A., Poh, T.M. et al. (2019a) Does oil palm agriculture help alleviate poverty? A multidimensional counterfactual assessment of oil palm development in Indonesia. World Development 120, 105-117.

Santika, T., Wilson, K.A., Meijaard, E., Budiharta, S., Law, E.A. et al. (2019b) Changing landscapes, livelihoods and village welfare in the context of oil palm development. Land Use Policy 87, 104073. 
Schroeder, W., Oliva, P., Giglio, L., \& Csiszar, I. A. (2014). The New VIIRS 375m active fire detection data product: algorithm description and initial assessment. Remote Sensing of Environment 143, 85-96.

Setiawan, A.M., Koesmaryono, Y., Faqih, A. \& Gunawan, D. (2017) Observed and blended gauge-satellite precipitation estimates perspective on meteorological drought intensity over South Sulawesi, Indonesia. IOP Conference Series: Earth and Environmental Science 54, 012040.

Shrestha, N.K., Qamer, F.M., Pedreros, D., Murthy, M.S.R., Wahid, S.M. et al. (2017) Evaluating the accuracy of Climate Hazard Group ( $\mathrm{CHG}$ ) satellite rainfall estimates for precipitation based drought monitoring in Koshi basin, Nepal. Journal of Hydrology: Regional Studies 13, 138-151.

Singh, S., Singh, D.R., Chand, S., Birah, A. \& Roy, S.D. (2015) Analysis of perspectives of self-sufficiency in vegetable production under tropical conditions. International Journal of Vegetable Science 21, 53-68.

Sloan, S., Locatelli, B., Wooster, M.J. \& Gaveau, D.L. (2017) Fire activity in Borneo driven by industrial land conversion and drought during El Niño periods, 1982-2010. Global Environmental Change 47, 95-109.

Sofan, P., Bruce, D., Jones, E. \& Marsden, J. (2019) Detection and validation of tropical peatland flaming and smouldering using Landsat-8 SWIR and TIRS Bands. Remote Sensing 11, 465.

Sugiarto, Y., Atmaja, T. \& Nurhasanah, S. (2018) Evaluation of the use of data reanalysis for climate regionalization. IOP Conference Series: Earth and Environmental Science 187, 012062.

Sze, J.S. \& Lee, J.S.H. (2019) Evaluating the social and environmental factors behind the 2015 extreme fire event in Sumatra, Indonesia. Environmental Research Letters 14, 015001.

Taufik, M., Torfs, P.J., Uijlenhoet, R., Jones, P.D., Murdiyarso, D. et al. (2017) Amplification of wildfire area burnt by hydrological drought in the humid tropics. Nature Climate Change 7, 428.

Thu, T.P., Moeliono, M., Wong, G.Y. \& Brockhaus, M. (2018) The politics of swidden: A case study from Nghe An and Son La in Vietnam. Land Use Policy. Available at: https://doi.org/10.1016/j.landusepol.2017.10.057.

Thung, P.H. (2018) A case study on the persistence of swidden agriculture in the context of post-2015 anti-haze regulation in West Kalimantan. Human Ecology 46, 197-205.

US Climate Prediction Center (2018) Historical El Niño/La Niña Episodes (1950-present).

Vadrevu, K.P., Csiszar, I., Ellicott, E., Giglio, L., Badarinath, K.V.S. et al. (2013) Hotspot analysis of vegetation fires and intensity in the Indian region. IEEE Journal of Selected Topics in Applied Earth Observations and Remote Sensing 6, 224-238.

Van der Werf, G.R. (2015) Indonesian Fire Season Progression. Available at: http://www.globalfiredata.org/updates.html\#2015_indonesia

Vernimmen, R.R.E., Hooijer, A., Aldrian, E. \& van Dijk, A.I.J.M. (2012) Evaluation and bias correction of satellite rainfall data for drought monitoring in Indonesia. Hydrology and Earth System Sciences 16, 133-146.

Watts, J.D., Tacconi, L., Hapsari, N., Irawan, S., Sloan, S. et al. (2019) Incentivizing compliance: Evaluating the effectiveness of targeted village incentives for reducing burning in Indonesia. Forest Policy and Economics. Available at: https://doi.org/10.1016/j.forpol.2019.101956 
Wijedasa, L.S., Jauhiainen, J., Könönen, M., Lampela, M., Vasander, H. et al. (2017) Denial of long-term issues with agriculture on tropical peatlands will have devastating consequences. Global Change Biology 23, 977-982. 


\section{SUPPLEMENTARY FIGURES}

\section{Interannual climate variation, land type and village livelihood effects on fires in Kalimantan, Indonesia}

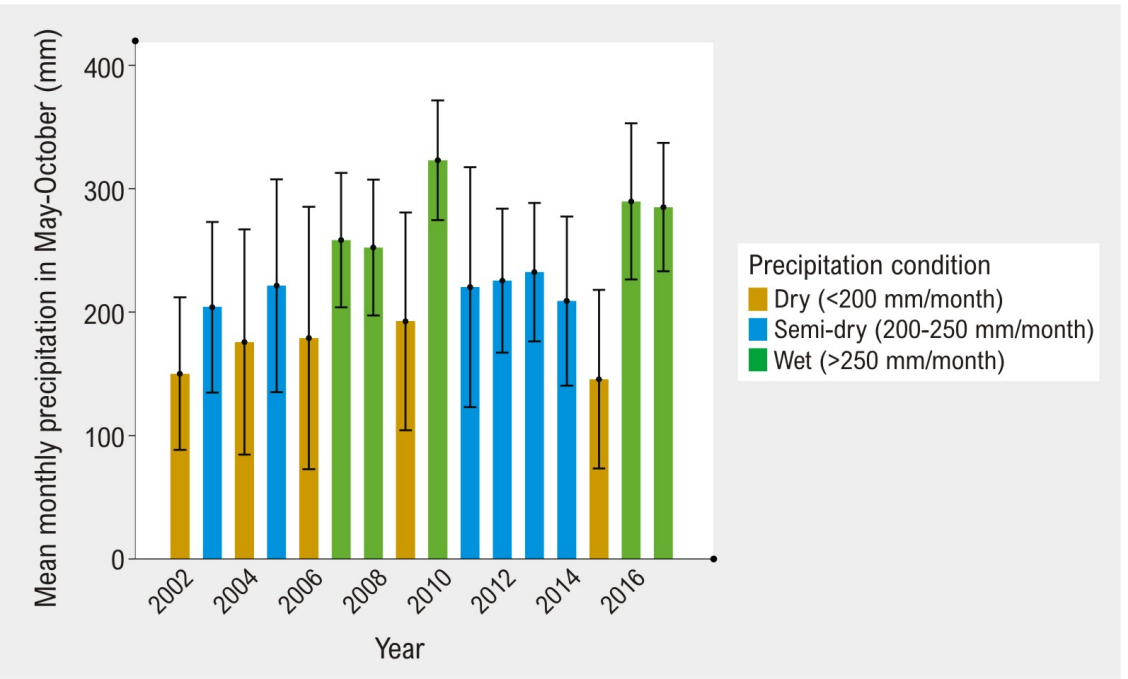

Fig. S1. Annual variability in mean monthly precipitation during the driest quarter (August-October) and the previous quarter (May-July), which has an effect on fire occurrence during the driest quarter (August-October), between 2002 and 2017 across Kalimantan. Error bars represent the 95\% confidence interval for the mean.
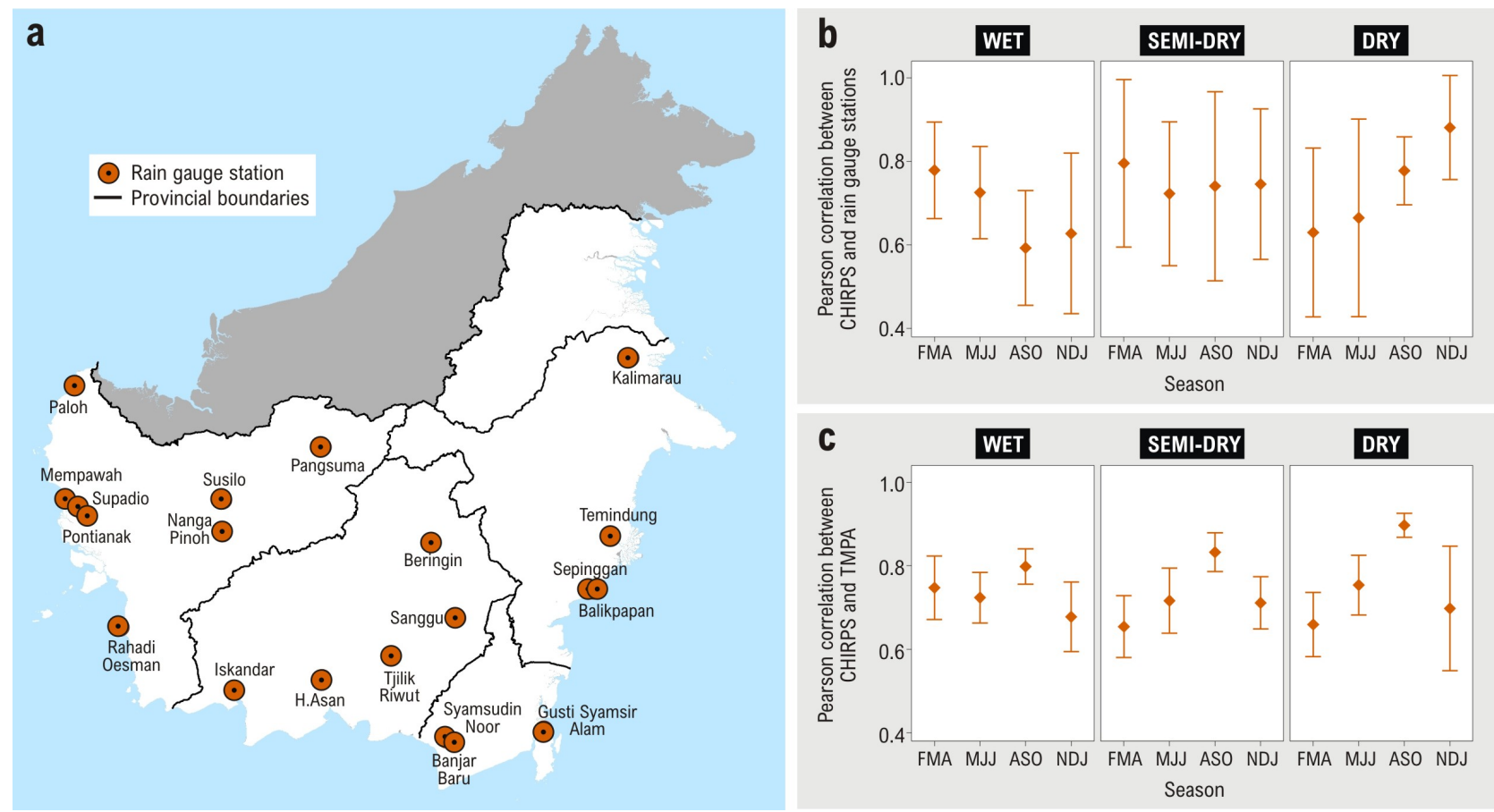

Fig. S2. (a) The distribution of major rain gauge stations in Kalimantan. (b) The relationship between the monthly precipitation estimates derived from CHIRPS and rain gauge measurements, and (c) between CHIRPS and TMPA data, by climate regime (wet, semi-dry and dry) and season (FMA=Feb-Apr, MJJ=Mar-Jul, ASO=Aug-Oct, NDJ=Nov-Jan) between 2000 and 2017. 


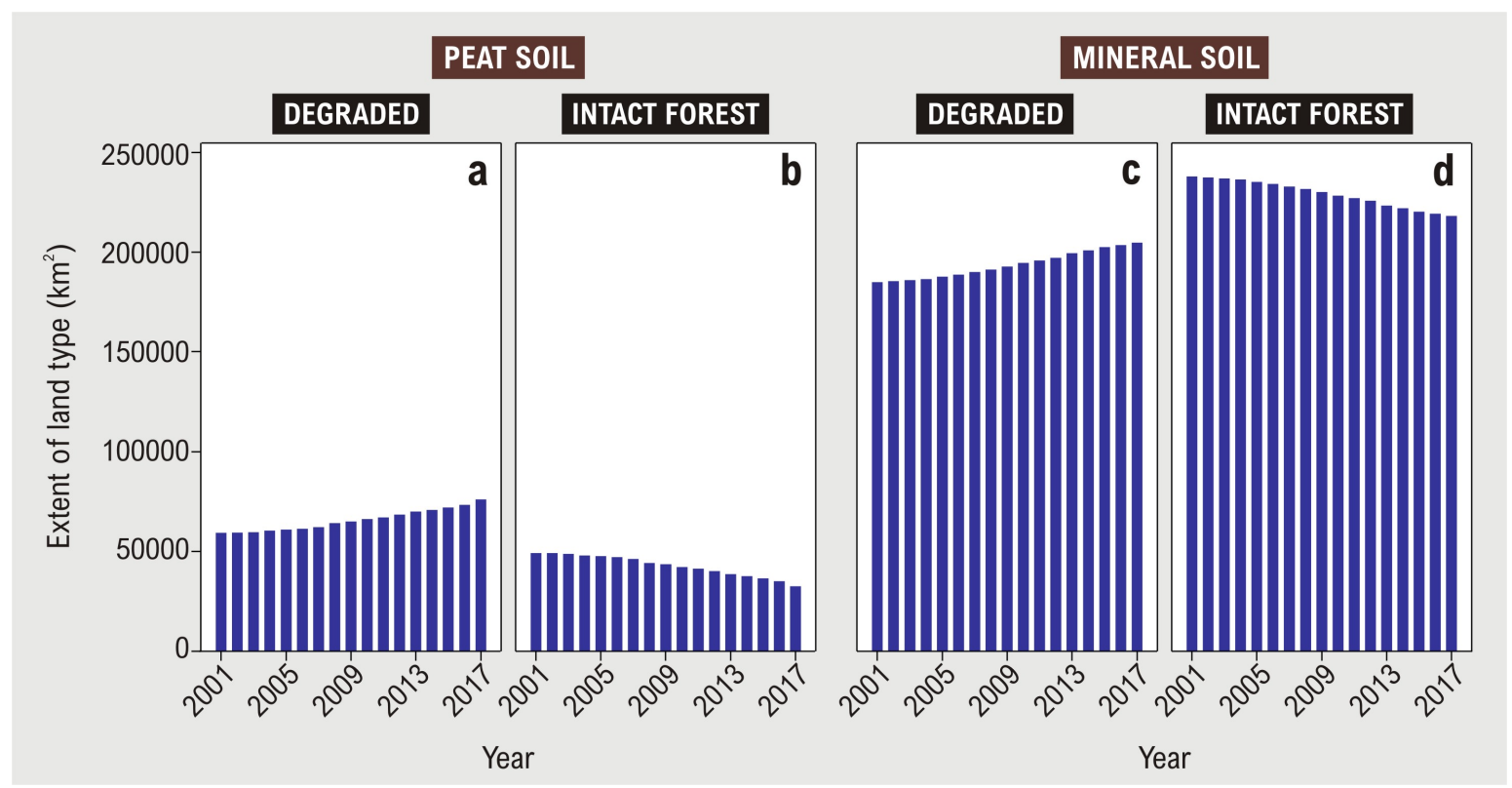

Fig. S3. Temporal change in the extent of different land types: (a) degraded peatland, (b) intact peat forest, (c) degraded land on mineral soil, and (d) intact forest on mineral soil, across Kalimantan between 2001 and 2017. The extent also represents the total number of $1 \times 1 \mathrm{~km}^{2}$ grid-cells used to estimate variable $\hat{F} I R E_{k l}$ (for each year $k$ and land type I) in analysis (2). The extent of intact forest (both on peat and mineral soils) had decreased through time replaced by degraded lands.

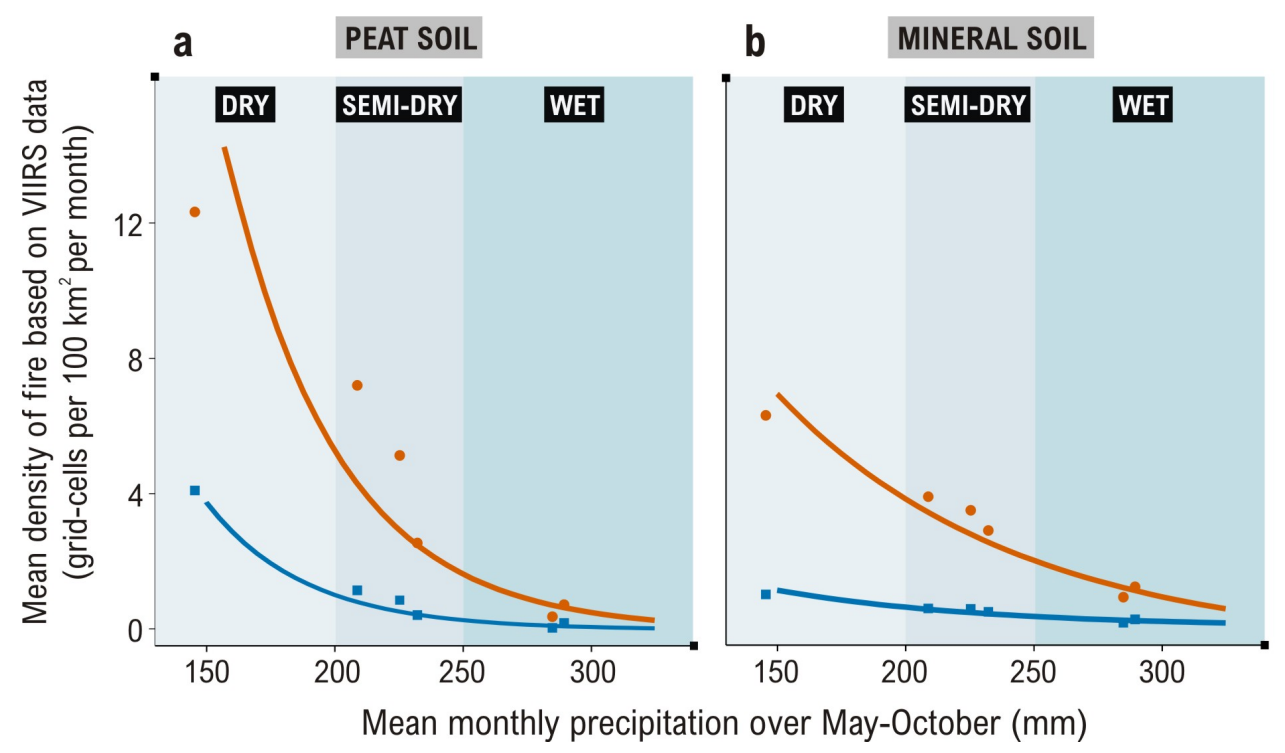

Fig. S4. Total number of $1 \times 1 \mathrm{~km}^{2}$ grid-cells with fires across Kalimantan detected by VIIRS between 2012 and 2017 on (a) peat soil and (b) mineral soil, by mean monthly precipitation condition over May-October in any given year: dry (precipitation <200 mm/month), semi-dry (precipitation 200-250 mm/month), and wet years (precipitation >250 $\mathrm{mm} / \mathrm{month})$. The line denotes the fitted exponential regression line of the total fire occurrence ( $\mathrm{y}$-axis) on the mean monthly precipitation amount over May-October (x-axis). 


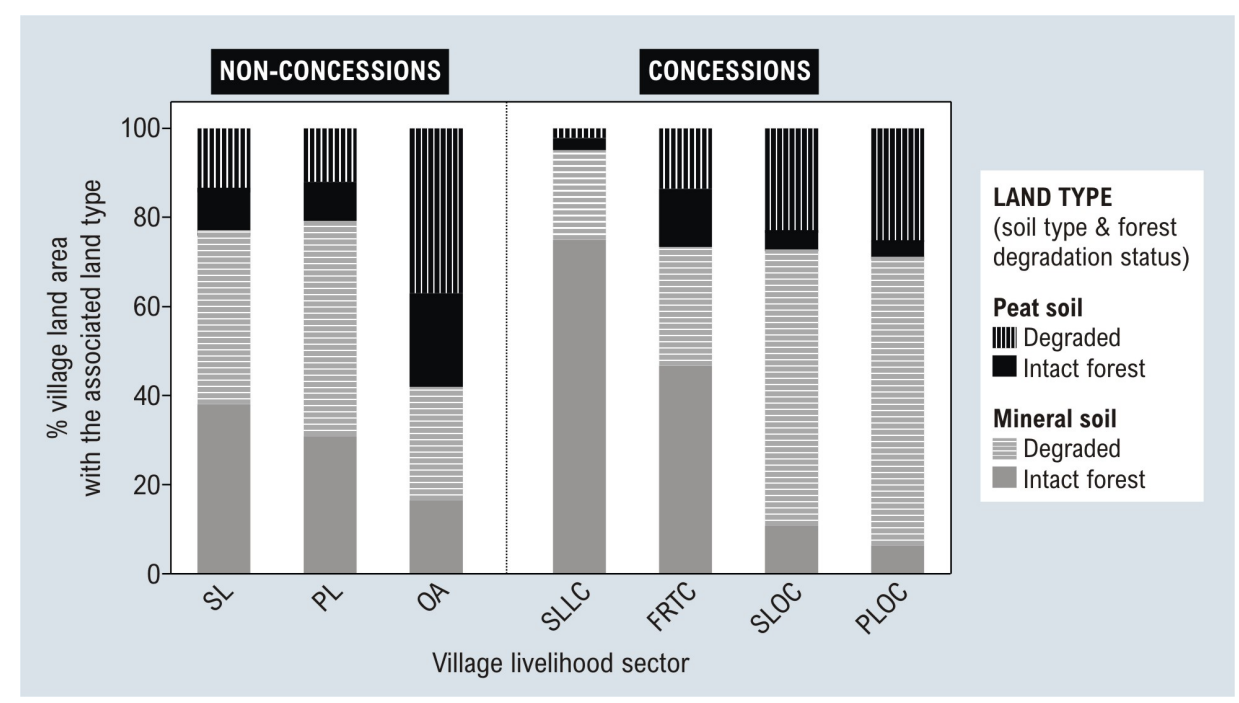

Fig. S5. The composition of different land types, i.e. soil type (peat or mineral soil) and forest degradation status (degraded or intact forest), in village with varying livelihood sectors: SL=Subsistence livelihoods outside any concessions, $\mathrm{PL}=$ agroforestry and polyculture plantations outside any concessions (mainly includes independent smallholder plantations), $\mathrm{OA}=$ other agricultural sectors outside any concessions (including horticulture, aquaculture, coastal fisheries, and livestock), SLLC=subsistence livelihoods within logging concessions on natural forest, FRTC=forestry within timber plantation concessions, SLOC=subsistence livelihoods within oil-palm concessions, and PLOC=plantations and other agricultural sectors within oil palm concessions. Villages with livelihood categories SLLC or FRTC have significant proportions of the village land areas located on intact forest on mineral soil, whereas villages with livelihood category SL or PL have moderate proportions of the village land areas on intact forest on mineral soil. Villages with livelihood category OA, SLOC, or PLOC have large proportion of the village land areas located on degraded peatland.

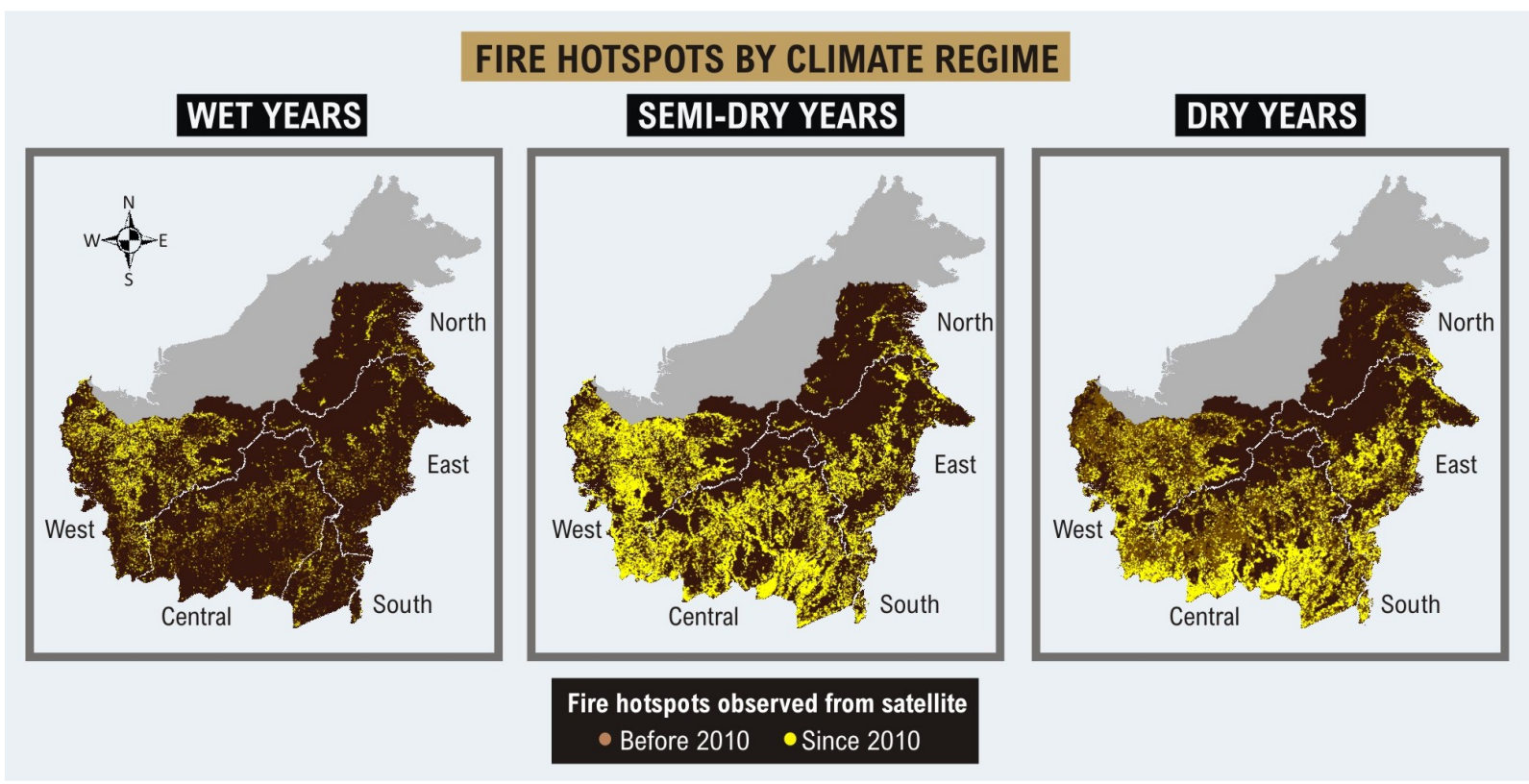

Fig. S6. Fire hotspots captured by satellite images (MODIS MCD4ML) for different climate regimes, showing spatial shift in fire occurrence patterns from wet years, to semi dry, then to dry years. Wet years (precipitation during the driest period >250 mm/month; coincided with La Niña episodes) include 2007, 2008, 2010, 2016 and 2017; Semi dry years (precipitation during the driest period 200-250 mm/month) include 2003, 2005, 2011, 2012, 2013 and 2014; Dry years (precipitation during the driest period < $200 \mathrm{~mm} /$ month; coincided with El Niño episodes) include 2002, 2004, 2006, 2009 and 2015. 


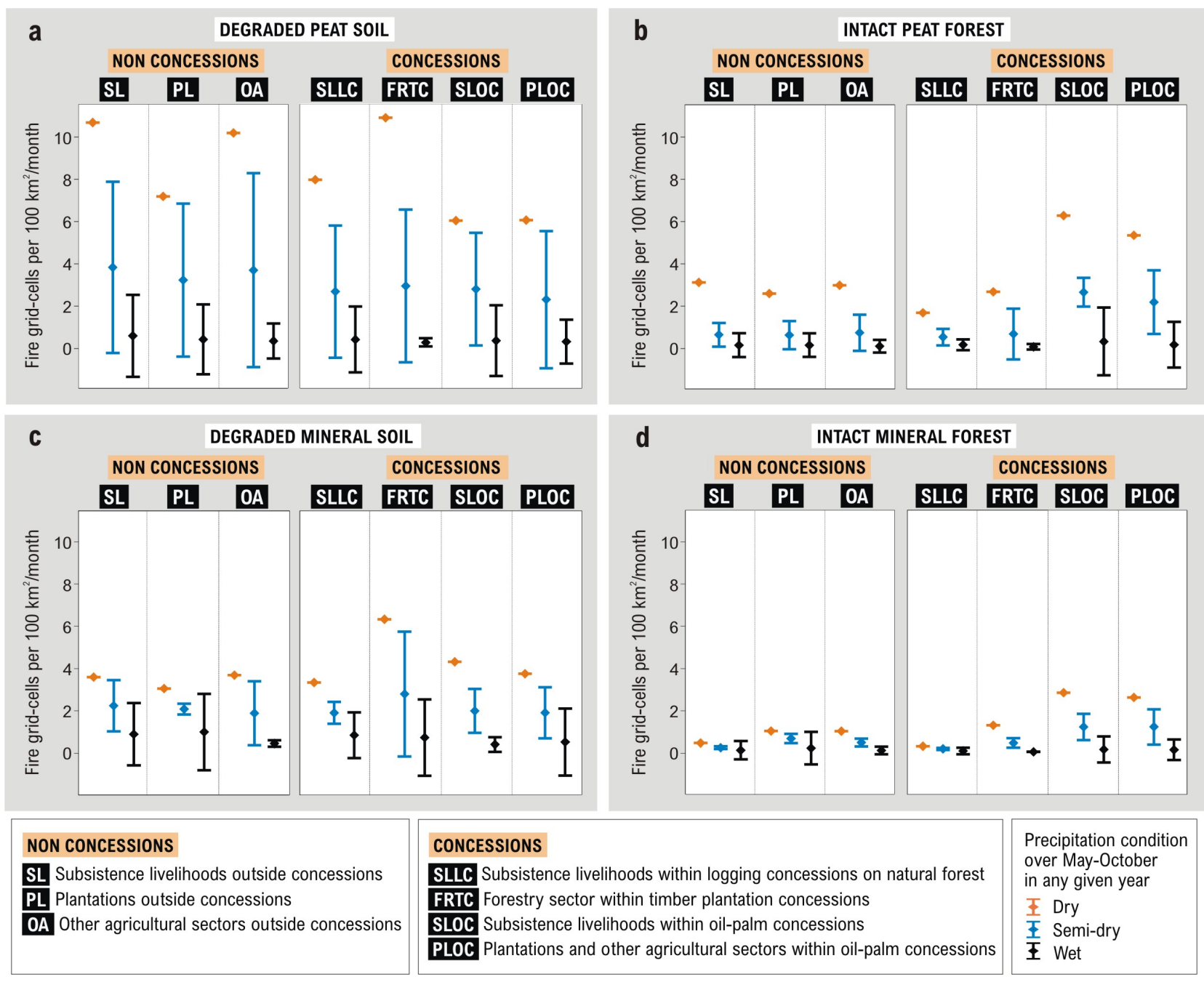

Fig. S7. Density of $1 \times 1 \mathrm{~km}^{2}$ grid-cells with fires per $1000 \mathrm{~km}^{2}$ per month detected by VIIRS between 2012 and 2017 across different village livelihood sectors in (a) degraded peat soil, (b) intact peat forest, (c) degraded land on mineral soil, and (d) intact forest on mineral soil, by precipitation condition over May-October in any given year: dry (precipitation <200 mm/month), semi-dry (precipitation 200-250 mm/month), and wet (precipitation >250 $\mathrm{mm} / \mathrm{month})$. 


\section{SUPPLEMENTARY TABLES}

\section{Interannual climate variation, land type and village livelihood effects on fires in Kalimantan, Indonesia}

Table S1. Landscape studies on the drivers of fire and haze that have been conducted in Indonesia, by chronological order. Data was collected in the web interface of Web of Science in July 2019. We used four terms related to fire in Indonesia to search in the Web of Science Core Collection, including: "fire", "smoke", "haze", "Indonesia". Drivers of fires assessed were categorized into three broad areas: $R=$ interannual rainfall variability, $L=$ land type (soil, land cover), $\mathrm{C}=$ community characteristics (land tenure, stakeholders, political economy). This list indicates that past landscape-based studies on the drivers of fire and haze typically fall into two broad themes: (1) broad-scale analysis (island or larger) of the impact of interannual rainfall variability (El Niño events) and land type (soil and land cover), and (2) local-scale analysis (up to province) of the impact of land type (soil and land cover) and community characteristics (land tenure, stakeholders, political economy).

\begin{tabular}{|c|c|c|c|c|}
\hline $\begin{array}{c}\text { Reference } \\
\text { (chronological order) }\end{array}$ & $\begin{array}{l}\text { Study area } \\
\text { (Local: up to province } \S \\
\text { Broad: island or larger *) }\end{array}$ & $\begin{array}{l}\text { Soil } \\
\text { type }^{\mp}\end{array}$ & $\begin{array}{l}\text { Year of fire } \\
\text { assessment }\end{array}$ & $\begin{array}{l}\text { Drivers of fires assessed } \\
\text { (broad themes) }\end{array}$ \\
\hline Stolle \& Lambin 2003 & $\begin{array}{l}\text { Lampung, South Sumatra, } \\
\text { Jambi and Riau provinces, } \\
\text { Sumatra * }\end{array}$ & Both & 1992-1993 & $\begin{array}{l}\text { Transmigration, logging concessions, } \\
\text { land cover, long-term climate (LC) }\end{array}$ \\
\hline Stolle et al. 2003 & Jambi, Sumatra ${ }^{\S}$ & Both & 1992-1993 & $\begin{array}{l}\text { Land use zone, transmigration, logging } \\
\text { concessions, land cover, long-term } \\
\text { climate (LC) }\end{array}$ \\
\hline Usup et al. 2004 & $\begin{array}{l}\text { Palangka Raya and Pulang } \\
\text { Pisau, Central Kalimantan } \S\end{array}$ & Peat soil & $1981-2003$ & Rainfall variability, land cover (RL) \\
\hline Dennis et al. 2005 & $\begin{array}{l}8 \text { sites in Borneo and } \\
\text { Sumatra * }\end{array}$ & Both & 1973-2000 & $\begin{array}{l}\text { Land use, land cover, agro-industrial } \\
\text { and logging concessions (LC) }\end{array}$ \\
\hline Hope et al. 2005 & Kutai East Kalimantan $\S$ & Peat soil & 2001 & $\begin{array}{l}\text { Soil characteristics, historical land use } \\
\text { (LC) }\end{array}$ \\
\hline Dennis \& Colfer 2006 & East Kutai, East Kalimantan $\S$ & $\begin{array}{l}\text { Mineral } \\
\text { soil }\end{array}$ & $1983-2000$ & $\begin{array}{l}\text { Land use zone, land cover, logging } \\
\text { concessions (LC) }\end{array}$ \\
\hline Fuller \& Murphy 2006 & Kalimantan * & Both & 1996-2001 & $\begin{array}{l}\text { Rainfall variability, land cover, soil type } \\
\text { (RL) }\end{array}$ \\
\hline Takakai et al. 2006 & $\begin{array}{l}\text { Palangka Raya, Central } \\
\text { Kalimantan } \S\end{array}$ & Peat soil & $2002-2004$ & Rainfall variability, land cover (RL) \\
\hline Russel-Smith et al. 2007 & Nusa Tenggara Timur $\S$ & $\begin{array}{l}\text { Mineral } \\
\text { soil }\end{array}$ & $2002-2004$ & $\begin{array}{l}\text { Land use, community characteristics } \\
\text { (LC) }\end{array}$ \\
\hline Field \& Shen 2008 & Indonesia * & Both & $1997-2006$ & $\begin{array}{l}\text { Rainfall variability, land cover, soil type } \\
\text { (RL) }\end{array}$ \\
\hline Putra et al. 2008 & $\begin{array}{l}\text { Mega rice project (MRP), } \\
\text { Central Kalimantan § }\end{array}$ & Peat soil & $1997-2007$ & Rainfall variability, land cover (RL) \\
\hline Tansey et al. 2008 & $\begin{array}{l}\text { Mega rice project (MRP), } \\
\text { Central Kalimantan }\end{array}$ & Peat soil & $2002-2005$ & Rainfall variability, vegetation types (RL) \\
\hline Van der Werf et al. 2008 & $\begin{array}{l}\text { Indonesia, Malaysia, and } \\
\text { Papua New Guinea * }\end{array}$ & Both & $2000-2006$ & Rainfall variability, soil type (RL) \\
\hline Field et al. 2009 & Kalimantan and Sumatra * & Both & $1997-2006$ & Rainfall variability, soil type $(\mathrm{RL})$ \\
\hline
\end{tabular}

\footnotetext{
${ }^{\mp}$ Peat soil, mineral soil, or both
} 
Table S1. Continued.

\begin{tabular}{|c|c|c|c|c|}
\hline $\begin{array}{c}\text { Reference } \\
\text { (chronological order) }\end{array}$ & $\begin{array}{c}\text { Study area } \\
\text { (Local: up to province } \$ \\
\text { Broad: island or larger *) }\end{array}$ & $\begin{array}{l}\text { Soil } \\
\text { type }^{\mp}\end{array}$ & $\begin{array}{l}\text { Year of fire } \\
\text { assessment }\end{array}$ & $\begin{array}{l}\text { Drivers of fires assessed } \\
\text { (broad themes) }\end{array}$ \\
\hline Langner \& Siegert 2009 & Borneo * & Both & 1995-2008 & Rainfall variability, soil type (RL) \\
\hline Hoscilo et al. 2011 & $\begin{array}{l}\text { Mega rice project (MRP) } \\
\text { Central Kalimantan } \S\end{array}$ & Peat soil & 1973-2005 & Rainfall variability, land cover (RL) \\
\hline Tosca et al. 2011 & Kalimantan and Sumatra * & Both & $2001-2009$ & Rainfall variability, land cover (RL) \\
\hline Wooster et al. 2012 & Borneo * & Both & $1980-2000$ & Rainfall variability, land cover (RL) \\
\hline Yulianti et al. 2012 & Indonesia * & Both & $2002-2011$ & $\begin{array}{l}\text { Rainfall variability, soil type, land cover } \\
\text { (RL) }\end{array}$ \\
\hline Hyer et al. 2013 & Indonesia * & Both & 2008-2011 & Rainfall variability, soil type (RL) \\
\hline Hayasaka et al. 2014 & Kalimantan * & Both & 2002 & $\begin{array}{l}\text { Rainfall variability, soil type, land cover } \\
\text { (RL) }\end{array}$ \\
\hline Marlier et al. 2015 & Indonesia * & Both & $2001-2010$ & Land cover, land tenure (LC) \\
\hline Gaveau et al. 2014 & Sumatra * & Both & 2013 & Soil type, land cover, land tenure (LC) \\
\hline Spessa et al. 2015 & Kalimantan * & Both & $1997-2010$ & $\begin{array}{l}\text { Rainfall variability, soil type, land cover } \\
(\mathrm{RL})\end{array}$ \\
\hline Atwood et al. 2016 & $\begin{array}{l}\text { Sebangau, Central Kalimantan } \\
\S\end{array}$ & Peat soil & 2015 & Land cover, land tenure (LC) \\
\hline Cattau et al. 2016 & $\begin{array}{l}\text { Sebangau-Katingan and Mega } \\
\text { rice project (MRP), Central } \\
\text { Kalimantan } \S\end{array}$ & Peat soil & $2000-2010$ & $\begin{array}{l}\text { Land cover, land tenure, agro-industrial } \\
\text { concessions (LC) }\end{array}$ \\
\hline Koplitz et al. 2016 & Kalimantan and Sumatra * & Both & 2015 & $\begin{array}{l}\text { Land cover, land tenure, agro-industrial } \\
\text { concessions (LC) }\end{array}$ \\
\hline Prasetyo et al. 2016 & Jambi, Sumatra $\S$ & Both & $2000-2015$ & $\begin{array}{l}\text { Rainfall variability, soil type, land cover } \\
\text { (LC) }\end{array}$ \\
\hline Fernandes et al. 2017 & Kalimantan and Sumatra * & Both & $2000-2014$ & Rainfall variability, soil type (RL) \\
\hline Purnomo et al. 2017 & Riau, Sumatra ${ }^{\S}$ & Both & 2015 & $\begin{array}{l}\text { Land cover, political economy, patron } \\
\text { and patronage (LC) }\end{array}$ \\
\hline Sloan et al. 2017 & Kalimantan * & Both & $1982-2010$ & $\begin{array}{l}\text { Rainfall variability, soil type, land cover } \\
\text { (RL) }\end{array}$ \\
\hline Sumarga 2017 & Central Kalimantan $\S$ & Both & 2015 & Land cover, soil type, land tenure (LC) \\
\hline Sze \& Lee 2019 & $\begin{array}{l}\text { Riau, Jambi, and South } \\
\text { Sumatra provinces } \S\end{array}$ & Both & 2015 & $\begin{array}{l}\text { Land cover, soil type, community } \\
\text { characteristics (LC) }\end{array}$ \\
\hline SUMMARY & $\begin{array}{l}*=18 \text { studies } \\
\S=15 \text { studies }\end{array}$ & & & $\begin{array}{l}\mathrm{RL}=18 \text { studies } \\
\mathrm{LC}=15 \text { studies }\end{array}$ \\
\hline
\end{tabular}

Themes:
$\mathrm{RL}^{*}=72.2 \% ; \mathrm{RL} \S=27.8 \% \longrightarrow$ Broad-scale analysis of the effects of rainfall variability and land type (soil and land cover)
$L C^{*}=33.3 \% ; L C^{\S}=66.7 \% \rightarrow$ Local-scale analysis of the effects of land type (soil and land cover) and community characteristics (land tenure, stakeholders, political economy)

\footnotetext{
${ }^{\mp}$ Peat soil, mineral soil, or both
} 


\section{References Table S1}

Atwood, E.C., Englhart, S., Lorenz, E., Halle, W., Wiedemann, W. et al. (2016) Detection and characterization of low temperature peat fires during the 2015 fire catastrophe in Indonesia using a new high-sensitivity fire monitoring satellite sensor (FireBird). PLoS One 11, p.e0159410.

Cattau, M.E., Harrison, M.E., Shinyo, I., Tungau, S., Uriarte, M. et al. (2016) Sources of anthropogenic fire ignitions on the peat-swamp landscape in Kalimantan, Indonesia. Global Environmental Change 39, 205-219.

Dennis, R.A. \& Colfer, C.P. (2006) Impacts of land use and fire on the loss and degradation of lowland forest in 19832000 in East Kutai District, East Kalimantan, Indonesia. Singapore Journal of Tropical Geography 27, 30-48.

Dennis, R.A., Mayer, J., Applegate, G., Chokkalingam, U., Colfer, C.J.P. et al. (2005) Fire, people and pixels: linking social science and remote sensing to understand underlying causes and impacts of fires in Indonesia. Human Ecology 33, 465-504.

Fernandes, K., Verchot, L., Baethgen, W., Gutierrez-Velez, V., Pinedo-Vasquez, M. et al. (2017) Heightened fire probability in Indonesia in non-drought conditions: the effect of increasing temperatures. Environmental Research Letters 12, p.054002.

Field, R.D., Van Der Werf, G.R. \& Shen, S.S. (2009) Human amplification of drought-induced biomass burning in Indonesia since 1960. Nature Geoscience 2, 185.

Fuller, D.0. \& Murphy, K. (2006) The ENSO-fire dynamic in insular Southeast Asia. Climatic Change 74, 435-455.

Gaveau, D.L., Salim, M.A., Hergoualc'h, K., Locatelli, B., Sloan, S. et al. (2014) Major atmospheric emissions from peat fires in Southeast Asia during non-drought years: evidence from the 2013 Sumatran fires. Scientific Reports 4,6112 .

Hayasaka, H., Noguchi, I., Putra, E.I., Yulianti, N. \& Vadrevu, K. (2014) Peat-fire-related air pollution in Central Kalimantan, Indonesia. Environmental Pollution 195, 257-266.

Hope, G., Chokkalingam, U. \& Anwar, S. (2005) The stratigraphy and fire history of the Kutai Peatlands, Kalimantan, Indonesia. Quaternary Research 64, 407-417.

Hoscilo, A., Page, S.E., Tansey, K.J. \& Rieley, J.O. (2011) Effect of repeated fires on land-cover change on peatland in southern Central Kalimantan, Indonesia, from 1973 to 2005. International Journal of Wildland Fire 20, 578588.

Hyer, E.J., Reid, J.S., Prins, E.M., Hoffman, J.P., Schmidt, C.C. et al. (2013) Patterns of fire activity over Indonesia and Malaysia from polar and geostationary satellite observations. Atmospheric Research 122, 504-519.

Koplitz, S.N., Mickley, L.J., Marlier, M.E., Buonocore, J.J., Kim, P.S. et al. (2016) Public health impacts of the severe haze in Equatorial Asia in September-October 2015: demonstration of a new framework for informing fire management strategies to reduce downwind smoke exposure. Environmental Research Letters 11, 094023.

Langner, A. \& Siegert, F. (2009) Spatiotemporal fire occurrence in Borneo over a period of 10 years. Global Change Biology 15, 48-62.

Marlier, M.E., DeFries, R.S., Kim, P.S., Koplitz, S.N., Jacob, D.J. et al. (2015) Fire emissions and regional air quality impacts from fires in oil palm, timber, and logging concessions in Indonesia. Environmental Research Letters 10, 085005.

Prasetyo, L.B., Dharmawan, A.H., Nasdian, F.T. \& Ramdhoni, S. (2016) Historical forest fire occurrence analysis in Jambi Province during the period of 2000-2015: its distribution \& land cover trajectories. Procedia Environmental Sciences 33, 450-459. 
Purnomo, H., Shantiko, B., Sitorus, S., Gunawan, H., Achdiawan, R. et al. (2017) Fire economy and actor network of forest and land fires in Indonesia. Forest Policy and Economics 78, 21-31.

Putra, E.I., Hayasaka, H., Takahashi, H. \& Usup, A. (2008) Recent peat fire activity in the mega rice project area, Central Kalimantan, Indonesia. Journal of Disaster Research 3, 1-6.

Russell-Smith, J., Djoeroemana, S., Maan, J. \& Pandanga, P. (2007) Rural livelihoods and burning practices in savanna landscapes of Nusa Tenggara Timur, eastern Indonesia. Human Ecology 35, 345-359.

Sloan, S., Locatelli, B., Wooster, M.J. \& Gaveau, D.L. (2017) Fire activity in Borneo driven by industrial land conversion and drought during El Niño periods, 1982-2010. Global Environmental Change 47, 95-109.

Spessa, A.C., Field, R.D., Pappenberger, F., Langner, A., Englhart, S. et al. (2015) Seasonal forecasting of fire over Kalimantan, Indonesia. Natural Hazards and Earth System Science 15, 429-442.

Stolle, F., Chomitz, K.M., Lambin, E.F. \& Tomich, T.P. (2003) Land use and vegetation fires in Jambi Province, Sumatra, Indonesia. Forest Ecology and Management 179, 277-292.

Stolle, F. \& Lambin, E.F. (2003) Interprovincial and interannual differences in the causes of land-use fires in Sumatra, Indonesia. Environmental Conservation 30, 375-387.

Sumarga, E. (2017) Spatial indicators for human activities may explain the 2015 fire hotspot distribution in Central Kalimantan Indonesia. Tropical Conservation Science 10, 1-9.

Sze, J.S. \& Lee, J.S. (2019) Evaluating the social and environmental factors behind the 2015 extreme fire event in Sumatra, Indonesia. Environmental Research Letters 14, 015001.

Takakai, F., Morishita, T., Hashidoko, Y., Darung, U., Kuramochi, K. et al. (2006) Effects of agricultural land-use change and forest fire on N20 emission from tropical peatlands, Central Kalimantan, Indonesia. Soil Science \& Plant Nutrition 52, 662-674.

Tansey, K., Beston, J., Hoscilo, A., Page, S.E. \& Paredes Hernández, C.U. (2008) Relationship between MODIS fire hot spot count and burned area in a degraded tropical peat swamp forest in Central Kalimantan, Indonesia. Journal of Geophysical Research: Atmospheres 113, D23112.

Tosca, M.G., Randerson, J.T., Zender, C.S., Nelson, D.L., Diner, D.J. et al. (2011) Dynamics of fire plumes and smoke clouds associated with peat and deforestation fires in Indonesia. Journal of Geophysical Research: Atmospheres 116, D08207.

Usup, A., Hashimoto, Y., Takahashi, H. \& Hayakasa, H. (2004) Combustion and thermal characteristics of peat fire in tropical peatland in Central Kalimantan, Indonesia. Tropics 14, 1-19.

Van der Werf, G.R., Dempewolf, J., Trigg, S.N., Randerson, J.T., Kasibhatla, P.S. et al. (2008) Climate regulation of fire emissions and deforestation in equatorial Asia. Proceedings of the National Academy of Sciences 105, 2035020355

Wooster, M.J., Perry, G.L. \& Zoumas, A. (2012) Fire, drought and El Niño relationships on Borneo (Southeast Asia) in the pre-MODIS era (1980-2000). Biogeosciences 16, 317-40.

Yulianti, N., Hayasaka, H. \& Usup, A. (2012) Recent forest and peat fire trends in Indonesia: The latest decade by MODIS hotspot data. Global Environmental Research 16, 105-116. 
Table S2. Lists of data used in the study, describing spatial and temporal resolutions, and approach to estimate missing data in some years.

\begin{tabular}{|c|c|c|c|c|c|c|c|c|c|c|c|c|c|c|c|c|c|c|c|}
\hline \multirow{2}{*}{$\begin{array}{l}\text { Data } \\
\left({ }^{*} \text { for validation; }\right. \\
\S \text { see Methods for detail } \\
\text { estimation approach) }\end{array}$} & \multirow[t]{2}{*}{ Resolution } & \multicolumn{18}{|c|}{$\begin{array}{c}\text { Availability of data }{ }^{\mp} \\
(\mathrm{x}=\text { available, year=approximated from the previously available data) }\end{array}$} \\
\hline & & $\begin{array}{l}2 \\
0 \\
0 \\
0\end{array}$ & $\begin{array}{l}2 \\
0 \\
0 \\
1\end{array}$ & $\begin{array}{l}2 \\
0 \\
0 \\
2\end{array}$ & $\begin{array}{l}2 \\
0 \\
0 \\
3\end{array}$ & $\begin{array}{l}2 \\
0 \\
0 \\
4\end{array}$ & $\begin{array}{l}2 \\
0 \\
0 \\
5\end{array}$ & $\begin{array}{l}2 \\
0 \\
0 \\
6\end{array}$ & $\begin{array}{l}2 \\
0 \\
0 \\
7\end{array}$ & $\begin{array}{l}2 \\
0 \\
0 \\
8\end{array}$ & $\begin{array}{l}2 \\
0 \\
0 \\
9\end{array}$ & $\begin{array}{l}2 \\
0 \\
1 \\
0\end{array}$ & $\begin{array}{l}2 \\
0 \\
1 \\
1\end{array}$ & $\begin{array}{l}2 \\
0 \\
1 \\
2\end{array}$ & $\begin{array}{l}2 \\
0 \\
1 \\
3\end{array}$ & $\begin{array}{l}2 \\
0 \\
1 \\
4\end{array}$ & $\begin{array}{l}2 \\
0 \\
1 \\
5\end{array}$ & $\begin{array}{l}2 \\
0 \\
1 \\
6\end{array}$ & $\begin{array}{l}2 \\
0 \\
1 \\
7\end{array}$ \\
\hline
\end{tabular}

FIRE OCCURRENCE

\begin{tabular}{|c|c|c|c|c|c|c|c|c|c|c|c|c|c|c|c|c|c|c|c|}
\hline MODIS MCD14ML & $1 \mathrm{~km}$ & $x$ & $x$ & $X$ & $X$ & $x$ & $X$ & $X$ & $x$ & $x$ & $X$ & $x$ & $x$ & $x$ & $x$ & $x$ & $x$ & $x$ & $x$ \\
\hline VIIRS VNP14_IMG * & $375 \mathrm{~m}$ & $x$ & $x$ & $x$ & $x$ & $x$ & $x$ & $x$ & $x$ & $x$ & $x$ & $x$ & $x$ & $x$ & $x$ & $x$ & $x$ & $x$ & $x$ \\
\hline
\end{tabular}

CLIMATE (PRECIPITATION)

\begin{tabular}{|c|c|c|c|c|c|c|c|c|c|c|c|c|c|c|c|c|c|c|c|}
\hline CHIRPS & 5 km & X & $X$ & $X$ & $X$ & $X$ & $X$ & $X$ & $X$ & $X$ & $X$ & $X$ & $X$ & $X$ & $X$ & $X$ & $X$ & $X$ & $x$ \\
\hline TMPA 3B43 * & 25 km & X & $x$ & $X$ & $x$ & $X$ & X & X & X & $x$ & $x$ & $x$ & $x$ & $x$ & X & X & X & $X$ & X \\
\hline Rain gauge observations ${ }^{\star}$ & $\begin{array}{l}\text { (20 stations } \\
\text { across } \\
\text { Kalimantan) }\end{array}$ & X & $x$ & X & X & $X$ & X & $x$ & X & X & X & X & $x$ & $x$ & X & $x$ & $x$ & $x$ & $x$ \\
\hline
\end{tabular}

\section{LAND TYPE}

Soil (peat or mineral soil) $125 \mathrm{~m} \quad \mathrm{x}$

Natural forest extent in $200030 \mathrm{~m} \quad x$

Global Forest Change $\quad 30 \mathrm{~m}$

$\begin{array}{llllllllllllllllllllllllllll}\text { Resulting land type } & \S & 125 & m & x & x & x & x & x & x & x & x & x & x & x & x & x & x & x & x & x & x\end{array}$

LIVELIHOODS

\begin{tabular}{lllllllllllllllllllll}
\hline Livelihood sectors (PODES) & Village & $x$ & 2 & 2 & $x$ & 2 & $x$ & 2 & 2 & $x$ & 2 & 2 & $x$ & 2 & 2 & $x$ & 2 & 2 & 2 \\
& boundaries & & 0 & 0 & & 0 & & 0 & 0 & & 0 & 0 & & 0 & 0 & & 0 & 0 & 0 \\
& & & 0 & 0 & & 0 & & 0 & 0 & & 0 & 0 & & 1 & 1 & & 1 & 1 & 1 \\
& & 0 & 0 & & 3 & & 5 & 5 & & 8 & 8 & & 1 & 1 & & 4 & 4 & 4 \\
\hline Industrial concessions & Concession & $x$ & 2 & 2 & 2 & 2 & $x$ & 2 & 2 & 2 & 2 & $x$ & 2 & 2 & 2 & 2 & $x$ & 2 & 2 \\
(active or planted) & boundaries & & 0 & 0 & 0 & 0 & & 0 & 0 & 0 & 0 & & 0 & 0 & 0 & 0 & & 0 & 0 \\
& & & 0 & 0 & 0 & 0 & & 0 & 0 & 0 & 0 & & 1 & 1 & 1 & 1 & & 1 & 1 \\
& & & 0 & 0 & 0 & 0 & & 5 & 5 & 5 & 5 & & 0 & 0 & 0 & 0 & & 5 & 5
\end{tabular}

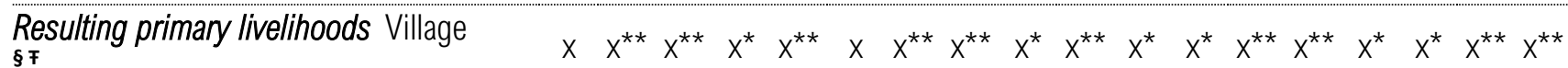

${ }^{\mp} \mathrm{X}$ = the resulting primary livelihoods was derived using available data on livelihood sector and concessions $x^{*}=$ the resulting primary livelihoods was derived using one approximated data on livelihood sector or concessions $\mathrm{X}^{* *}=$ the resulting primary livelihoods was derived using approximated data on both livelihood sector and concessions 
Table S3. Estimated effect (and the significance) of the mean monthly precipitation during the driest quarter (AugustOctober) and the previous quarter (May-July) (variable $\bar{R} A I N$, with continuous values) on monthly fire occurrence during the driest quarter (August-October) (variable $\bar{F} I R E$, with continuous values) (log-level regression model in Eq. 1; data size $n=16$ ) for $F R P \geq 1 \mathrm{MW}$ (all fires) and $F R P \geq 100 \mathrm{MW}$ (high intensity fires).

\begin{tabular}{|c|c|c|c|}
\hline \multirow[t]{2}{*}{ FRP } & \multicolumn{2}{|c|}{ Estimated parameters ( $p$-value $\not{x}$ ) } & \multirow[t]{2}{*}{ Model fit $\left(R^{2}\right)$} \\
\hline & Intercept $\left(\alpha_{0}\right)$ & $\bar{R} A I N\left(\alpha_{1}\right)$ & \\
\hline$\geq 1 \mathrm{MW}$ (all fires) & $12.26(\bullet \bullet \bullet)$ & $-0.02(\bullet \bullet)$ & 0.91 \\
\hline$\geq 100$ MW (high intensity fires) & $10.81(\bullet \bullet)$ & $-0.02(\bullet \bullet)$ & 0.89 \\
\hline
\end{tabular}

* $\cdots$-value $<0.001, \cdots p$-value $<0.01, \bullet p$-value $<0.05,{ }^{*} p$-value $<0.1$, ns non-significant with $p$-value $\geq 0.1$

Table S4. Estimated effects (and the significance) of land type (variable LTYPE, with categorical values: $1=$ intact forest on mineral soil (FM), 2 = degraded land on mineral soil (DM), 3 = intact peat forest (FP), 4 = degraded peatland (DP)) and the mean monthly precipitation during the driest quarter (August-October) and the previous quarter (MayJuly) (variable $\bar{R} A I N$, with continuous values) on density of fire per $100 \mathrm{~km}^{2}$ per month during the driest quarter (August-October) (variable FIRE, with continuous values) (Eq. 2; data size $n=64)$. $L T Y P E_{1}$, representing intact forest on mineral soil (FM), is the reference category.

\begin{tabular}{|c|c|c|c|c|c|}
\hline \multicolumn{5}{|c|}{ Estimated parameters ( $p$-value $\not \mathbf{x})$} & \multirow[t]{2}{*}{ Model fit $\left(R^{2}\right)$} \\
\hline $\begin{array}{c}\text { Intercept } \\
\left(\beta_{0}\right)\end{array}$ & $\bar{R} A I N\left(\beta_{1}\right)$ & $\begin{array}{c}\angle T Y P E_{2} \\
(\mathrm{DM}) \\
\left(\beta_{2,2}\right)\end{array}$ & $\begin{array}{c}L^{L T Y P E_{3}} \\
(\mathrm{FP}) \\
\left(\beta_{2,3}\right)\end{array}$ & $\begin{array}{c}\angle T Y P E_{4} \\
(\mathrm{DP}) \\
\left(\beta_{2,4}\right)\end{array}$ & \\
\hline $2.95(\bullet \bullet)$ & $-0.02(\bullet \bullet \bullet)$ & $1.72(\bullet \bullet \bullet)$ & $0.84(\bullet \bullet)$ & $1.91(\bullet \bullet)$ & 0.88 \\
\hline
\end{tabular}

* $\cdots p$-value $<0.001, \cdots p$-value $<0.01, \bullet p$-value $<0.05,{ }^{*} p$-value $<0.1$, ns non-significant with $p$-value $\geq 0.1$ 
Table S5. Estimated effects (and the significance) of village primary livelihood sector (variable LVHD, with categorical values: 1 = subsistence livelihoods outside any concessions (SL), 2 = agroforestry and polyculture plantations outside any concessions (PL), 3 = other agricultural sectors outside any concessions (including horticulture, aquaculture, coastal fisheries, and livestock) (OA), 4 = subsistence livelihoods within logging concessions on natural forest land (SLLC), 5 = forestry within timber plantation concessions (FRTC), 6 = subsistence livelihoods within oil palm concessions (SLOC), and $7=$ plantations and other agricultural sectors within oil palm concessions (PLOC)) on density of fire per $100 \mathrm{~km}^{2}$ per month during the driest quarter (August-October) (variable $\breve{F} I R E$, with continuous values), in different climate regimes (CLIM: wet, semi-dry and dry years) and land types (intact forest on mineral soil, degraded land on mineral soil, intact peat forest, and degraded peatland) (Eq. 3). $L V H D_{1}$, representing subsistence livelihoods outside any concessions (SL), is the reference category. Cell in grey represents livelihood category with significant effect on fire density compared to the reference category SL ( $p$-value $<0.1)$.

\begin{tabular}{|c|c|c|c|c|c|c|c|c|c|c|}
\hline \multirow[t]{4}{*}{ ID } & \multirow{4}{*}{$\begin{array}{l}\text { Land type } \\
\text { by Climate } \\
\text { regime }\end{array}$} & \multicolumn{7}{|c|}{ Estimated parameters ( $p$-value $\not{x}$ ) } & \multirow{4}{*}{$\begin{array}{c}\text { Data size } \\
\text { or number } \\
\text { of villages } \\
(n)\end{array}$} & \multirow{4}{*}{$\begin{array}{c}\text { Model fit } \\
\left(R^{2}\right)\end{array}$} \\
\hline & & \multirow{3}{*}{$\begin{array}{c}\text { Intercept } \\
\left(\delta_{0}\right)\end{array}$} & \multicolumn{2}{|c|}{ Non-concessions } & \multicolumn{4}{|c|}{ Concessions } & & \\
\hline & & & $\begin{array}{c}\mathrm{LVHD_{2 }} \\
\text { (P) }\end{array}$ & $\begin{array}{c}V H D_{3} \\
(\mathrm{OA})\end{array}$ & $\begin{array}{l}\angle V H D_{4} \\
(S H)\end{array}$ & $\begin{array}{l}L V H D_{5} \\
(F R T C)\end{array}$ & $\begin{array}{l}\angle V H D_{6} \\
\end{array}$ & $\begin{array}{l}\angle V H D_{7} \\
\angle P I O C)\end{array}$ & & \\
\hline & & & $\left(\delta_{1,2}\right)$ & $\left(\delta_{1,3}\right)$ & $\left(\delta_{1,4}\right)$ & $\left(\delta_{1,5}\right)$ & $\left(\delta_{1,6}\right)$ & $\left(\delta_{1,7}\right)$ & & \\
\hline \multicolumn{11}{|c|}{ Wet years } \\
\hline \multirow[t]{2}{*}{1} & Intact forest on & 0.12 & 0.10 & 0.02 & -0.04 & -0.01 & 0.18 & 0.24 & 955 & 0.57 \\
\hline & mineral soil & (ns) & (ns) & (ns) & (ns) & (ns) & $\left({ }^{*}\right)$ & $(\bullet)$ & & \\
\hline \multirow[t]{2}{*}{2} & Degraded land & 0.67 & 0.01 & -0.12 & -0.06 & -0.02 & -0.01 & -0.16 & 4431 & 0.7 \\
\hline & on mineral soil & $(\bullet \bullet)$ & (ns) & (ns) & (ns) & (ns) & (ns) & (ns) & & \\
\hline \multirow[t]{2}{*}{3} & Intact & 0.19 & 0.06 & -0.13 & 0.05 & -0.09 & 0.28 & 0.23 & 294 & 0.4 \\
\hline & peat forest & (ns) & (ns) & (ns) & $(\mathrm{ns})$ & (ns) & $(\bullet)$ & $\left({ }^{*}\right)$ & & \\
\hline \multirow[t]{3}{*}{4} & Degraded & 0.45 & 0.00 & -0.15 & -0.14 & -0.16 & -0.07 & -0.13 & 942 & 0.58 \\
\hline & peatland & $(\bullet)$ & (ns) & (ns) & (ns) & (ns) & (ns) & (ns) & & \\
\hline & Semi-dry years & & & & & & & & & \\
\hline \multirow[t]{2}{*}{5} & Intact forest on & 0.24 & 0.18 & 0.19 & -0.07 & 0.11 & 0.77 & 0.70 & 978 & 0.8 \\
\hline & mineral soil & $(\bullet)$ & (ns) & (ns) & (ns) & (ns) & $(\bullet)$ & $(\bullet \bullet)$ & & \\
\hline \multirow[t]{2}{*}{6} & Degraded land & 1.58 & 0.05 & 0.15 & -0.18 & 0.15 & 0.08 & -0.04 & 4409 & 0.7 \\
\hline & on mineral soil & $(\bullet \bullet)$ & (ns) & (ns) & (ns) & (ns) & (ns) & (ns) & & \\
\hline \multirow[t]{2}{*}{7} & Intact & 0.53 & 0.21 & 0.06 & 0.00 & 0.02 & 1.23 & 0.68 & 315 & 0.68 \\
\hline & peat forest & $(\bullet)$ & (ns) & (ns) & (ns) & (ns) & $(\bullet \bullet)$ & $(\bullet)$ & & \\
\hline \multirow[t]{3}{*}{8} & Degraded & 2.39 & 0.39 & 0.16 & -0.67 & 0.38 & 0.09 & 0.34 & 920 & 0.40 \\
\hline & peatland & $(\bullet)$ & (ns) & (ns) & (ns) & (ns) & (ns) & (ns) & & \\
\hline & Dry years & & & & & & & & & \\
\hline \multirow[t]{2}{*}{9} & Intact forest on & 0.47 & 0.39 & 0.24 & 0.15 & 0.04 & 1.90 & 1.93 & 1008 & 0.6 \\
\hline & mineral soil & (ns) & (ns) & (ns) & (ns) & (ns) & $(\cdots)$ & $(\cdots)$ & & \\
\hline \multirow[t]{2}{*}{10} & Degraded land & 3.42 & 0.12 & 0.43 & -0.31 & 0.99 & 0.81 & 0.40 & 4379 & 0.5 \\
\hline & on mineral soil & $(\bullet \bullet)$ & (ns) & (ns) & (ns) & $(\bullet)$ & $(\bullet)$ & (ns) & & \\
\hline \multirow[t]{2}{*}{11} & Intact & 2.28 & 0.17 & 0.08 & -0.82 & -0.15 & 1.82 & 1.08 & 343 & 0.47 \\
\hline & peat forest & $(\bullet \bullet)$ & (ns) & (ns) & (ns) & (ns) & $(\bullet)$ & $\left({ }^{*}\right)$ & & \\
\hline \multirow[t]{2}{*}{12} & Degraded & 7.70 & 0.55 & 0.53 & -0.96 & 0.84 & 0.12 & 0.09 & 892 & 0.62 \\
\hline & peatland & $(\bullet)$ & (ns) & (ns) & (ns) & (ns) & (ns) & (ns) & & \\
\hline
\end{tabular}

* $\cdots p$-value $<0.001, \cdots p$-value $<0.01, \cdot p$-value $<0.05,{ }^{*} p$-value $<0.1$, ns non-significant with $p$-value $\geq 0.1$ 